\title{
Structural Implications of STAT3 and STAT5 SH2 Domain Mutations
}

\author{
Elvin D. de Araujo ${ }^{1,2}$, Anna Orlova ${ }^{3}{ }^{\mathbb{D}}$, Heidi A. Neubauer ${ }^{3} \mathbb{D}$, Dávid Bajusz ${ }^{4} \mathbb{D}^{\text {, }}$ \\ Hyuk-Soo Seo ${ }^{5,6}{ }^{\mathbb{D}}$, Sirano Dhe-Paganon ${ }^{5,6}$, György M. Keserú ${ }^{4}$, Richard Moriggl ${ }^{3}$ and \\ Patrick T. Gunning 1,2,*
}

1 Centre for Medicinal Chemistry, University of Toronto at Mississauga, Mississauga, ON L5L 1C6, Canada; e.dearaujo@mail.utoronto.ca

2 Department of Chemical \& Physical Sciences, University of Toronto at Mississauga, Mississauga, ON L5L 1C6, Canada

3 Institute of Animal Breeding and Genetics, University of Veterinary Medicine, A-1210 Vienna, Austria; Anna.Orlova@vetmeduni.ac.at (A.O.); Heidi.Neubauer@vetmeduni.ac.at (H.A.N.); Richard.Moriggl@vetmeduni.ac.at (R.M.)

4 Medicinal Chemistry Research Group, Research Center for Natural Sciences, 1117 Budapest, Hungary; bajusz.david@ttk.mta.hu (D.B.); keseru.gyorgy@ttk.mta.hu (G.M.K.)

5 Department of Cancer Biology, Dana-Farber Cancer Institute, Department of Biological Chemistry \& Molecular Pharmacology, Harvard Medical School, Boston, MA 02115, USA; hux@crystal.harvard.edu (H.-S.S.); dhepag@crystal.harvard.edu (S.D.-P.)

6 Department of Biological Chemistry, Department of Biological Chemistry \& Molecular Pharmacology, Harvard Medical School, Boston, MA 02115, USA

* Correspondence: patrick.gunning@utoronto.ca; Tel.: +1-905-569-4588

Received: 30 September 2019; Accepted: 5 November 2019; Published: 8 November 2019

\begin{abstract}
Src Homology 2 (SH2) domains arose within metazoan signaling pathways and are involved in protein regulation of multiple pleiotropic cascades. In signal transducer and activator of transcription (STAT) proteins, SH2 domain interactions are critical for molecular activation and nuclear accumulation of phosphorylated STAT dimers to drive transcription. Sequencing analysis of patient samples has revealed the $\mathrm{SH} 2$ domain as a hotspot in the mutational landscape of STAT proteins although the functional impact for the vast majority of these mutations remains poorly characterized. Despite several well resolved structures for $\mathrm{SH} 2$ domain-containing proteins, structural data regarding the distinctive STAT-type SH2 domain is limited. Here, we review the unique features of STAT-type SH2 domains in the context of all currently reported STAT3 and STAT5 $\mathrm{SH} 2$ domain clinical mutations. The genetic volatility of specific regions in the $\mathrm{SH} 2$ domain can result in either activating or deactivating mutations at the same site in the domain, underscoring the delicate evolutionary balance of wild type STAT structural motifs in maintaining precise levels of cellular activity. Understanding the molecular and biophysical impact of these disease-associated mutations can uncover convergent mechanisms of action for mutations localized within the STAT SH2 domain to facilitate the development of targeted therapeutic interventions.
\end{abstract}

Keywords: STAT3; STAT5; SH2 domain; mutations; cancer; autosomal-dominant hyper IgE syndrome; inflammatory hepatocellular adenomas; T-cell large granular lymphocytic leukemia; T-cell prolymphocytic leukemia; growth hormone insensitivity syndrome

\section{Introduction}

Several key cellular pathways converge on the multidomain signal transducer and activator of transcription (STAT) proteins highlighting their importance in the development and progression 
of oncogenic and malignant diseases. Conventional STAT activation is initiated by cytokine or growth-factor interactions with extracellular receptors, stimulating SH2 domain-mediated recruitment of tyrosine kinases and STAT isoforms to the receptor cytoplasmic domains [1,2]. Nuclear translocation and accumulation of the resulting phosphorylated STAT dimers facilitates transcription of a wide array of gene products involved in proliferation and cellular survival including C-MYC [3], BCL-XL [3], MCL-1 [4], FOXP3 [5], BCL-2 [6], HIF [7], D-type cyclins [8], IGF-1 [9], and self-regulation of STAT3/STAT5 [10]. Normal STAT function is dependent on the SH2 domain which arbitrates homo- or hetero-STAT dimerization as well as multiple protein-protein interactions. As such, structurally altered SH2 domains exhibit considerable effects on STAT activity, leading to either hyperactivated or refractory STAT mutants. These critical roles in governing the transcriptional capacity, coupled with the relatively shallow binding surfaces elsewhere on the protein, resulted in the STAT SH2 domain dominating therapeutic interest for small molecule inhibitor development and intervention [11-15]. However, currently there are no clinical drug candidates directly targeting the STAT protein family. This is partially due to the limited structural data available on the STAT SH2 domains or their mutated disease-associated counterparts, and further compounded by observations that STAT SH2 domains are distinct from those found in other well characterized systems such as Src kinase. Here, we summarize structural features of STAT-type SH2 domains in the context of STAT3/STAT5 disease-associated mutations, and discuss their effects on protein activity, as well as potential new druggable pockets within the STAT SH2 domain.

\section{Structure of STAT SH2 Domains}

SH2 domains are modular units that arose within multicellular life, approximately 600 million years ago, and are therefore heavily tied to metazoan signal transduction [16]. There are 121 human SH2 domains that are classified into different groups based on their structural or phylogenetic characteristics [16]. Broadly, they have been classified into either STAT- or Src-type SH2 domains based on the presence of either an $\alpha$-helix (STAT-type) or $\beta$-sheet (Src-type) at the C-terminus [17]. Alternatively, phylogenetic analysis has categorized SH2 domain-containing proteins into 38 different sub-families [16]. Functional activity-based screens have also been employed to stratify SH2 domain-containing proteins into four categories based on the identity of the fifth residue in the $\beta D$ strand, which has been shown to be a critical determinant in phospho-peptide selectivity $[18,19]$. Despite different methods for classification, all SH2 domains contain conserved structural motifs that are canonical to the core function of phospho-Tyr (pY) peptide binding. These features represent an evolutionary compromise to preserving critical structural motifs while maintaining highly specific peptide recognition capacity.

The structure of an SH2 domain consists of a central anti-parallel $\beta$-sheet (with the three $\beta$-strands conventionally labeled $\beta \mathrm{B}-\beta \mathrm{D}$ ) interposed between two $\alpha$-helices ( $\alpha \mathrm{A}$ and $\alpha \mathrm{B}$ ), often referred to as the $\alpha \beta \beta \beta \alpha$ motif [16]. The structure and nomenclature for the motifs of STAT SH2 domains is shown in Figure $1 \mathrm{a}, \mathrm{b}$. The $\beta$-sheet partitions the $\mathrm{SH} 2$ domain into two subpockets, referred to as the $\mathrm{pY}$ (phosphate-binding) and pY+3 (specificity) pocket [16]. The pY pocket is formed by the $\alpha \mathrm{A}$ helix, the $\mathrm{BC}$ loop (region connecting $\beta \mathrm{B}-\beta C$ strands) and one face of the central $\beta$-sheet. The $\mathrm{pY}+3$ pocket is created by the opposite face of the $\beta$-sheet as well as residues from the $\alpha B$ helix and CD and BC* loops (regions connecting $\beta \mathrm{C}-\beta \mathrm{D}$ strands and $\alpha \mathrm{B}-\alpha \mathrm{C}$ helices, respectively). Both the $\mathrm{pY}$ and $\mathrm{pY}+3$ pockets are common targets for drug design due to well defined features and conserved residues. Within the $\mathrm{pY}+3$ pocket, there are additional clefts that also have drug targeting potential. This includes the C-terminal region of the $\mathrm{pY}+3$ pocket, also known as the evolutionary active region (EAR) [17]. The EAR contains an additional $\alpha$-helix $\left(\alpha B^{\prime}\right)$ in STAT-type SH2 domains, as opposed to the Src-type which harbors a $\beta$-sheet ( $\beta E$ and $\beta F$ although each strand is not always observed). Additionally, there is a cluster of non-polar residues (referred to as the hydrophobic system [20]) at the base of the $\mathrm{pY}+3$ pocket that assists in stabilizing the conformation of the $\beta$-sheet and maintaining the integrity of the overall SH2 domain. The $\alpha \mathrm{B}, \alpha \mathrm{B}^{\prime}$, and $\mathrm{BC}^{*}$ loop also participate in SH2-mediated STAT dimerization forming 
important cross-domain interactions. Therefore, residues in the $\mathrm{pY}+3$ pocket can have a dual effect on STAT dimerization capacity and phospho-peptide binding. Conventional phospho-peptide binding occurs perpendicular to the $\beta$-sheet with the peptide adopting a binding mode as illustrated with STAT1 in Figure 1c. The phospho-Tyr interacts with conserved amino acids in the pY pocket, while the C-terminal residues stretch across the $\mathrm{SH} 2$ domain into the $\mathrm{pY}+3$ pocket.

(a)
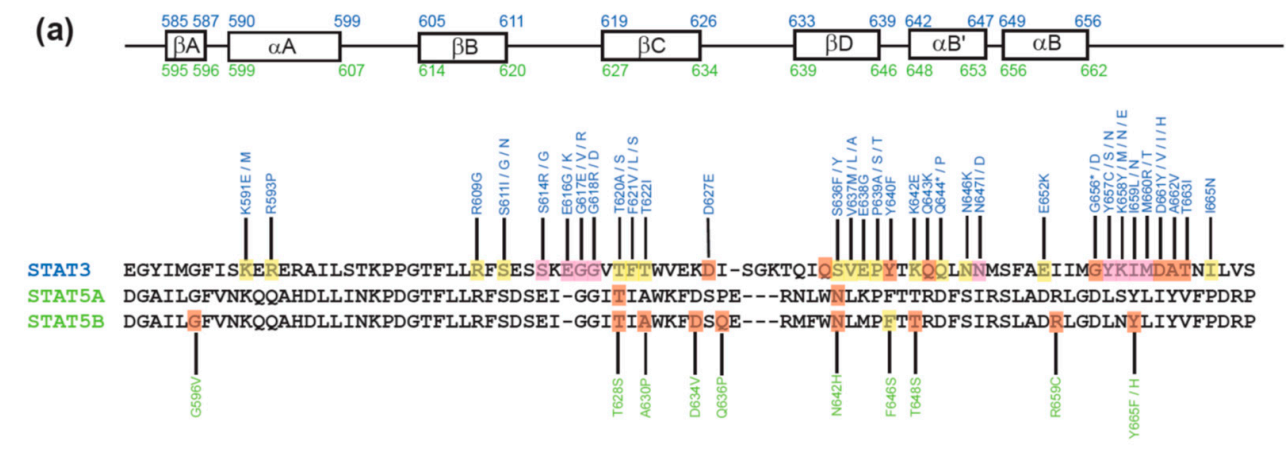

(b)

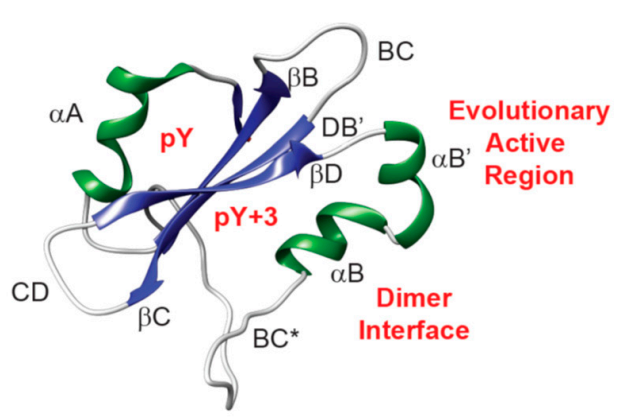

(d)

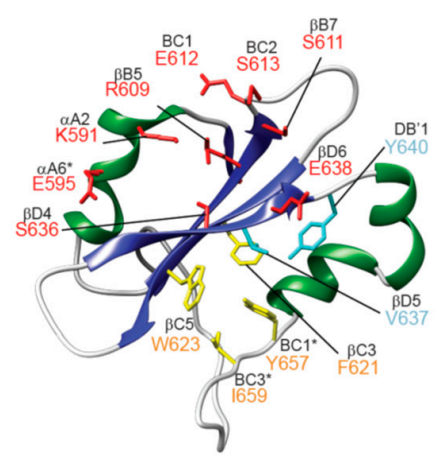

(f)

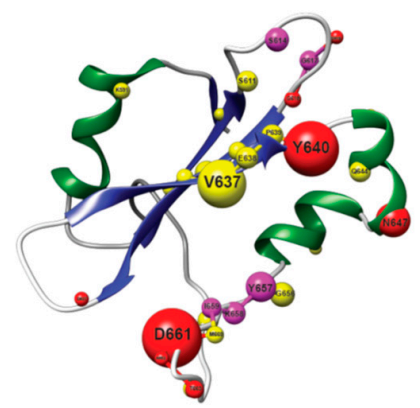

(c)

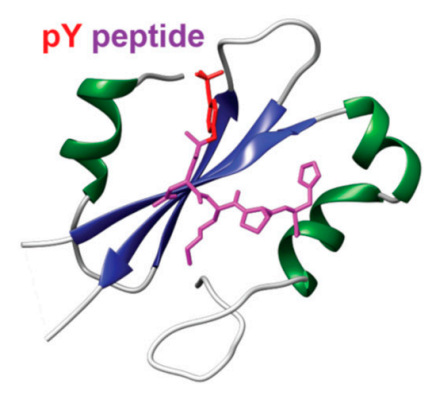

(e)

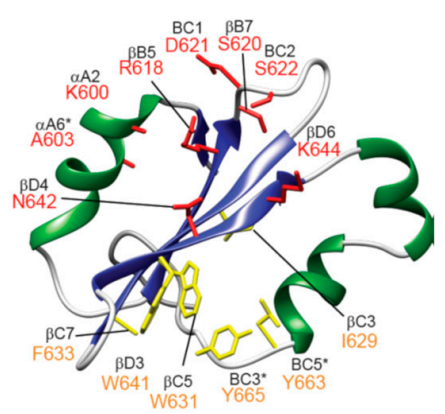

(g)

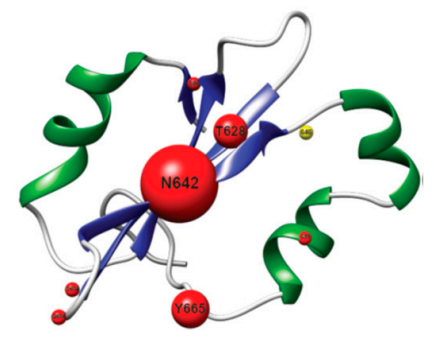

Figure 1. (a) Secondary structural motifs in STAT3 (blue) and STAT5 (green) with mutations annotated; (b) Structure of STAT3 SH2 domain; (c) Structure of pY-peptide-STAT1 SH2 domain. The pY residue is depicted in red with the C-terminal residues in violet; (d) Structure of STAT3 SH2 domain with Sheinerman residues (red), hydrophobic system residues (yellow) and the selectivity filter (cyan); 
(e) Structure of STAT5B SH2 domain with the same color scheme as above; (f) STAT3 SH2 domain with all mutations highlighted in spheres. The volume of each sphere is proportional to frequency of cases identified. Red spheres indicate an activating mutation, yellow spheres indicate a destabilizing mutation and magenta spheres represent sites where both activating and refractory mutations are observed; (g) STAT5B SH2 domain with all mutations highlighted in spheres. The color scheme is the same as in (f). Protein structures were visualized using Chimera [21] with PDB codes: 4E68 [22] (STAT3), 6MBW (STAT5B) [23], 1YVL (STAT1) [24].

These residues are critical for maintaining proper binding interactions to facilitate protein dimerization, and specific mutations here can alter normal STAT function. An issue of particular relevance for drug discovery is protein flexibility, and indeed, STAT SH2 domains exhibit a particularly flexible behavior even in sub-microsecond timescales $[23,25]$. Notably, the accessible volume of the pY pocket varies dramatically. Also, crystal structures do not necessarily preserve even the main, targetable pockets in an accessible state. This further underlines the importance of accounting for protein dynamics in STAT-directed drug discovery efforts.

\section{Disease-Associated Mutations in STAT3 and STAT5B SH2 Domains}

Sequencing analysis of patient samples has identified multiple point mutations within the SH2 domain of STAT3 (Table 1) and STAT5B (Table 2) leading to variable effects on physiological activity. In mice, homozygous disruption of STAT3 is embryonically lethal [26], and correspondingly germline homozygous loss-of-function (LOF) mutations have not been identified in humans. Heterozygous loss of STAT3 can be tolerated to different extents and contributes to immunological deficiencies, most commonly autosomal-dominant Hyper IgE syndrome (AD-HIES) as a result of a reduced STAT3-mediated Th17 T-cell response [27-29]. Classical STAT3 function is implicated in Th17 T-cell lineage commitment, through upregulation of ROR $\gamma \mathrm{t}$, promoting the release of IL-17 and IL-22. This stimulates transcription of genes associated with Th17 development. Loss of STAT3 function strongly diminishes Th17 T-cell expansion, thereby reducing the immunologic response leading to recurrent staphylococcal infections and exceedingly high levels of IgE that contribute to clinical presentations of eczema and eosinophilia.

Table 1. Disease-associated mutations in the STAT3 SH2 domain.

\begin{tabular}{|c|c|c|c|c|c|c|c|c|}
\hline Mutation & Position & Location & $\begin{array}{l}\text { Residue } \\
\text { Relevance }\end{array}$ & $\begin{array}{l}\text { Nucleotide } \\
\text { Substitution }\end{array}$ & Cases & Pathology & Type & Ref \\
\hline K591E & $\alpha \mathrm{A} 2$ & $\mathrm{pY}$ & Sheinerman & $1771 \mathrm{~A}>\mathrm{G}$ & 1 & AD-HIES & Germline & [30] \\
\hline K591M & $\alpha \mathrm{A} 2$ & $\mathrm{pY}$ & Sheinerman & $1772 \mathrm{~A}>\mathrm{T}$ & 1 & AD-HIES & Germline & [31] \\
\hline R593P & $\alpha \mathrm{A} 4$ & pY & - & $1778 \mathrm{G}>\mathrm{C}$ & 1 & AD-HIES & Germline & [32] \\
\hline R609G & $\beta B 5$ & pY & $\begin{array}{l}\text { Sheinerman\& } \\
\text { Signature }\end{array}$ & $1825 \mathrm{~A}>\mathrm{G}$ & 1 & AD-HIES & Germline & [33] \\
\hline S611N & $\beta B 7$ & pY & $\begin{array}{l}\text { \& Signature } \\
\text { Sheinerman }\end{array}$ & $1832 \mathrm{G}>\mathrm{A}$ & 2 & AD-HIES & Germline & {$[36,37]$} \\
\hline S611I & $\beta B 7$ & pY & $\begin{array}{l}\text { Sheinerman \& } \\
\text { Signature }\end{array}$ & $1832 \mathrm{G}>\mathrm{T}$ & 1 & AD-HIES & Germline & [38] \\
\hline S614G & BC3 & pY & Sheinerman & $18040 A>G$ & 1 & AD-HIES & Germline & [34] \\
\hline S614R & $\mathrm{BC} 3$ & pY & Sheinerman & $1842 C>G$ & 1 & HSTL & Somatic & [39-43] \\
\hline
\end{tabular}


Table 1. Cont

\begin{tabular}{|c|c|c|c|c|c|c|c|c|}
\hline Mutation & Position & Location & $\begin{array}{c}\text { Residue } \\
\text { Relevance }\end{array}$ & $\begin{array}{l}\text { Nucleotide } \\
\text { Substitution }\end{array}$ & Cases & Pathology & Type & Ref \\
\hline E616G & BC5 & pY & BC loop & $1847 \mathrm{~A}>\mathrm{G}$ & 1 & $\begin{array}{l}\text { DLBCL, } \\
\text { NOS }\end{array}$ & Somatic & [44] \\
\hline E616K & BC5 & $\mathrm{pY}$ & BC loop & $1846 \mathrm{G}>\mathrm{A}$ & 1 & NKTL & Somatic & [45] \\
\hline G617E & BC6 & pY & BC loop & $1850 \mathrm{G}>\mathrm{A}$ & 1 & AD-HIES & Germline & [46] \\
\hline G617V & $\mathrm{BC} 6$ & pY & BC loop & $1850 \mathrm{G}>\mathrm{T}$ & 1 & AD-HIES & Germline & [34] \\
\hline G617R & BC6 & $\mathrm{pY}$ & BC loop & $1849 \mathrm{G}>\mathrm{A}$ & 1 & $\begin{array}{l}\text { DLBCL, } \\
\text { NOS }\end{array}$ & Somatic & [44] \\
\hline \multirow{2}{*}{ G618R } & \multirow{2}{*}{ BC6 } & \multirow{2}{*}{$\mathrm{pY}$} & \multirow{2}{*}{ BC loop } & \multirow{2}{*}{$1852 \mathrm{G}>\mathrm{C}$} & 1 & $\mathrm{ALK}^{-} \mathrm{ALCL}$ & \multirow{2}{*}{ Somatic } & \multirow{2}{*}[47,48]{} \\
\hline & & & & & 1 & T-LGLL & & \\
\hline G618D & BC6 & $\mathrm{pY}$ & BC loop & $1853 \mathrm{G}>\mathrm{A}$ & 2 & AD-HIES & Germline & {$[35,37]$} \\
\hline T620A & $\beta C 2$ & pY & - & $1858 \mathrm{~A}>\mathrm{G}$ & 2 & AD-HIES & Germline & {$[34,49]$} \\
\hline T620S & $\beta C 2$ & pY & - & $1859 C>G$ & 1 & AD-HIES & Germline & [33] \\
\hline F621V & $\beta \mathrm{C} 3$ & $\mathrm{pY}+3$ & Hydro. Sys. & $1861 \mathrm{~T}>\mathrm{G}$ & 3 & AD-HIES & Germline & {$[36,37,50]$} \\
\hline F621L & $\beta C 3$ & $\mathrm{pY}+3$ & Hydro. Sys. & $1863 C>G$ & 2 & AD-HIES & Germline & {$[51,52]$} \\
\hline F621S & $\beta C 3$ & $\mathrm{pY}+3$ & Hydro. Sys. & $1862 \mathrm{~T}>\mathrm{C}$ & 1 & AD-HIES & Germline & [53] \\
\hline T622I & $\beta C 4$ & pY & - & $1865 \mathrm{C}>\mathrm{T}$ & 4 & AD-HIES & Germline & {$[30,34,36]$} \\
\hline D627E & CD1 & & - & $1881 \mathrm{C}>\mathrm{A}$ & 1 & ATLL & Somatic & [54] \\
\hline S636F & $\beta \mathrm{D} 4$ & pY & Sheinerman & $1907 \mathrm{C}>\mathrm{T}$ & 1 & AD-HIES & Germline & [49] \\
\hline S636Y & $\beta \mathrm{D} 4$ & pY & Sheinerman & $1907 \mathrm{C}>\mathrm{A}$ & 1 & AD-HIES & Germline & [30] \\
\hline V637M & $\beta$ D5 & $\mathrm{pY}+3$ & Sel. Filter & $1909 \mathrm{G}>\mathrm{A}$ & 43 & AD-HIES & Germline & {$[30,32-37,49,52,55,56]$} \\
\hline V637L & ßD5 & $\mathrm{pY}+3$ & Sel. Filter & $1909 \mathrm{G}>\mathrm{T}$ & 1 & AD-HIES & Germline & [36] \\
\hline V637A & $\beta D 5$ & $\mathrm{pY}+3$ & Sel. Filter & $1910 \mathrm{~T}>\mathrm{C}$ & 1 & AD-HIES & Germline & {$[30]$} \\
\hline E638G & $\beta \mathrm{D} 6$ & pY & Sheinerman & $1913 A>G$ & 4 & AD-HIES & Germline & {$[49,51,57,58]$} \\
\hline P639A & $\beta D 7$ & $\mathrm{pY}+3$ & - & $1915 \mathrm{C}>\mathrm{G}$ & 1 & AD-HIES & Germline & [37] \\
\hline P639S & $\beta \mathrm{D} 7$ & $\mathrm{pY}+3$ & - & $1915 \mathrm{C}>\mathrm{T}^{*}$ & 2 & AD-HIES & Germline & {$[30,34]$} \\
\hline P639T & $\beta \mathrm{D} 7$ & $\mathrm{pY}+3$ & - & $1915 \mathrm{C}>\mathrm{A}$ & 1 & AD-HIES & Germline & [35] \\
\hline \multirow{9}{*}{ Y640F } & \multirow{9}{*}{$\mathrm{DB}^{\prime} 1$} & \multirow{9}{*}{$\mathrm{pY}+3$} & \multirow{9}{*}{ - } & \multirow{9}{*}{$1919 \mathrm{~A}>\mathrm{T}$} & 56 & T-LGLL & \multirow{9}{*}{ Somatic } & \multirow{9}{*}[43,44,47,48,57,59-69]{} \\
\hline & & & & & 2 & IHT & & \\
\hline & & & & & 3 & $\overline{\text { CLPD-NKs }}$ & & \\
\hline & & & & & 2 & NK-LGLL & & \\
\hline & & & & & 1 & $\begin{array}{l}\text { DLBCL, } \\
\text { NOS }\end{array}$ & & \\
\hline & & & & & 1 & ANKL & & \\
\hline & & & & & 1 & NKTL & & \\
\hline & & & & & 1 & Sezary & & \\
\hline & & & & & 3 & HSTL & & \\
\hline K642E & $\alpha \mathrm{B}^{\prime} 1$ & - & Dimer Inter & $1924 \mathrm{~A}>\mathrm{G}$ & 1 & AD-HIES & Germline & [34] \\
\hline Q643K & $\alpha \mathrm{B}^{\prime} 2$ & - & Dimer Inter & $1927 \mathrm{C}>\mathrm{A}$ & 1 & T-LGLL & Somatic & [68] \\
\hline Q644P & $\alpha \mathrm{B}^{\prime} 3$ & - & Dimer Inter & $1929 \mathrm{~A}>\mathrm{C}$ & 3 & AD-HIES & Germline & {$[52,70]$} \\
\hline Q644del & $\alpha B^{\prime} 3$ & - & Dimer Inter & 1930del CAG & 2 & AD-HIES & Germline & {$[35,36]$} \\
\hline N646K & $\alpha \mathrm{B}^{\prime} 5$ & $\mathrm{pY}+3$ & Dimer Inter & $1938 \mathrm{C}>\mathrm{G}$ & 2 & EOAD & Germline & [71] \\
\hline N647D & $\alpha B^{\prime} 6$ & $\mathrm{pY}+3$ & Dimer Inter & $1939 A>G$ & 8 & AD-HIES & Germline & {$[36,72]$} \\
\hline \multirow{3}{*}{ N647I } & \multirow{3}{*}{$\alpha \mathrm{B}^{\prime} 6$} & \multirow{3}{*}{$\mathrm{pY}+3$} & \multirow{3}{*}{ Dimer Inter } & \multirow{3}{*}{$1940 \mathrm{~A}>\mathrm{T}$} & 3 & CLPD-NK & & \\
\hline & & & & & 6 & T-LGLL & Somatic & {$[43,57,65,67]$} \\
\hline & & & & & 1 & HSTL & & \\
\hline E652K & $\alpha \mathrm{B} 3$ & $\mathrm{pY}+3$ & Dimer Inter & $1954 \mathrm{G}>\mathrm{A}$ & 1 & AD-HIES & Germline & [36] \\
\hline G656D & $\alpha \mathrm{B} 7$ & $\mathrm{pY}+3$ & Dimer Inter & $1967 \mathrm{G}>\mathrm{A}$ & 1 & T-LGLL & Somatic & [73] \\
\hline G656_Y657insF & $\alpha \mathrm{B} 7$ & $\mathrm{pY}+3$ & Hydro. Sys. & $\begin{array}{c}\text { 1968C }>\mathrm{T} ; \\
\text { 1969_1970insTTT }\end{array}$ & 1 & IHCA & Somatic & [66] \\
\hline Y657C & $\mathrm{BC}^{*}$ & $\mathrm{pY}+3$ & Hydro. Sys. & $1970 A>G$ & 5 & AD-HIES & Germline & {$[30,34,36,58]$} \\
\hline Y657S & $\mathrm{BC}^{*}$ & $\mathrm{pY}+3$ & Hydro. Sys. & $1970 \mathrm{~A}>\mathrm{C}$ & 1 & AD-HIES & Germline & [74] \\
\hline Y657N & $\mathrm{BC}^{*}$ & $\mathrm{pY}+3$ & Hydro. Sys. & $1969 \mathrm{~T}>\mathrm{A}$ & 1 & AD-HIES & Germline & [52] \\
\hline Y657ins & $\mathrm{BC}^{*}$ & $\mathrm{pY}+3$ & Hydro. Sys. & - & 1 & TCL & Somatic & [47] \\
\hline Y657dup & $\mathrm{BC}^{*}$ & $\mathrm{pY}+3$ & Hydro. Sys. & - & 3 & T-LGLL & Somatic & {$[48,65,72]$} \\
\hline
\end{tabular}


Table 1. Cont.

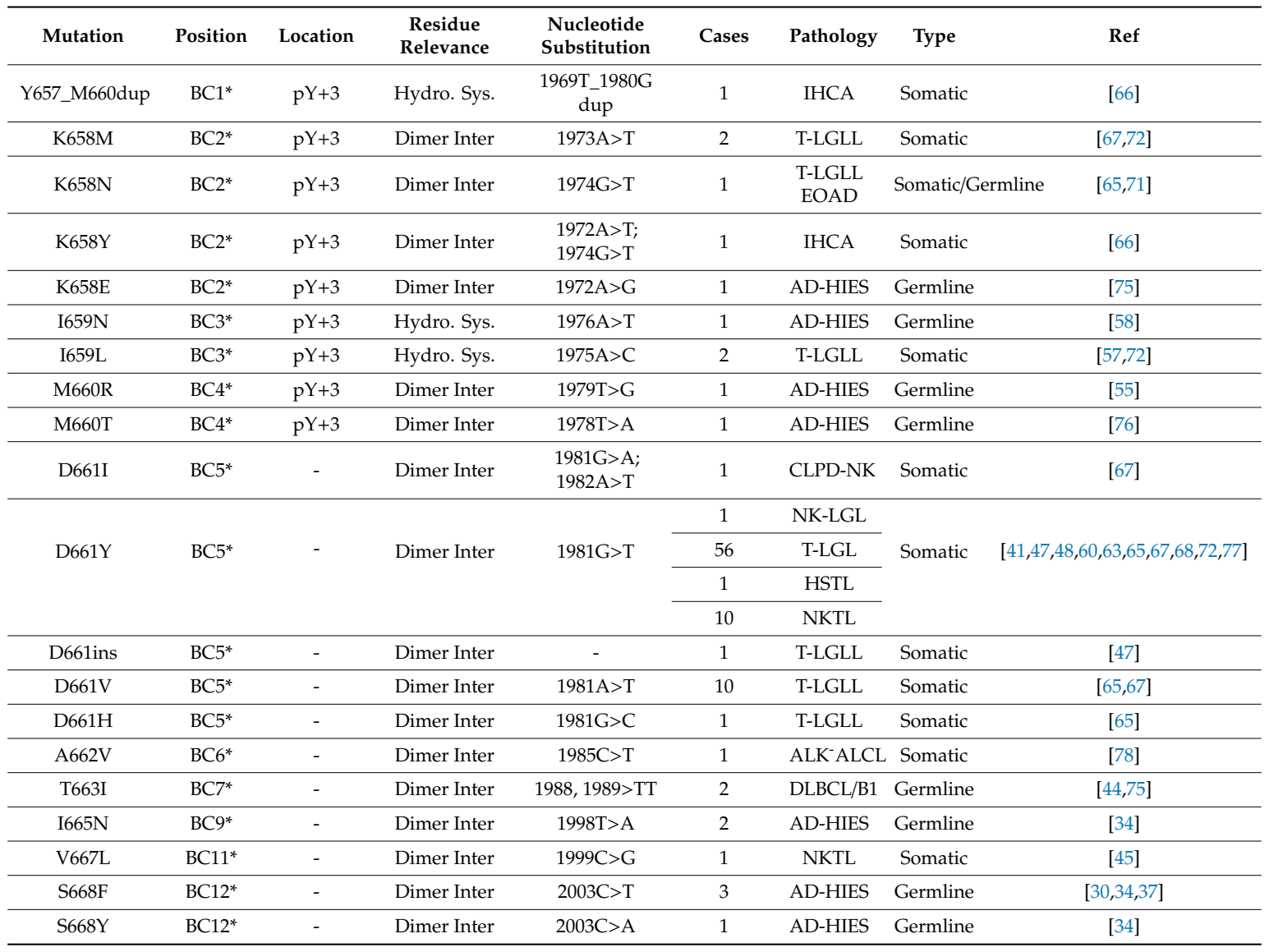

The final search date for mutations from medical case reports and literature was 30 August, 2019. Abbreviations: AD-HIES, autosomal-dominant Hyper IgE syndrome; ALK-ALCL, anaplastic lymphoma kinase negative anaplastic large cell lymphoma; ANKL, aggressive natural killer cell leukemia; ATLL, adult T-cell leukemia lymphoma; EOAD, early onset autoimmune disease; CLPD-NKs, Chronic lymphoproliferative disorders of natural killer cells; DLBCL, NOS, Diffuse large B-cell lymphoma, not-otherwise-specified; NKTL, extranodal NK/T-cell lymphoma; HSTL, Hepatosplenic T-cell lymphoma; IHAC, inflammatory hepatocellular adenomas; IHT, inflammatory hepatocellular tumors; NK-LGLL, Natural killer cell large granular lymphocytic leukemia; T-LGLL, T-cell large granular lymphocytic leukemia; TCL, $\gamma \delta$-T-cell lymphoma. 
Table 2. Disease-associated mutations in the STAT5B SH2 domain.

\begin{tabular}{|c|c|c|c|c|c|c|c|c|}
\hline Mutation & Position & Location & $\begin{array}{l}\text { Residue } \\
\text { Relevance }\end{array}$ & $\begin{array}{l}\text { Nucleotide } \\
\text { Substitution }\end{array}$ & Cases & Pathology & Type & Ref. \\
\hline G596V & $\beta \mathrm{A} 2$ & - & - & $1787 \mathrm{G}>\mathrm{T}$ & 1 & APL & Somatic & [79] \\
\hline \multirow{4}{*}{ T628S } & \multirow{4}{*}{$\beta C 2$} & \multirow{4}{*}{$\mathrm{pY}$} & \multirow{4}{*}{-} & \multirow{4}{*}{$1883 C>G$} & 11 & T-PLL & \multirow{4}{*}{ Somatic } & \multirow{4}{*}[43,80,81]{} \\
\hline & & & & & 1 & MEITL & & \\
\hline & & & & & 3 & HSTL & & \\
\hline & & & & & 1 & Eosinophilia & & \\
\hline A630P & $\beta C 4$ & pY & - & $1888 \mathrm{G}>\mathrm{C}$ & 1 & GHI & Germline* & [82] \\
\hline D634V & $\beta C 8$ & pY & - & $1901 \mathrm{~A}>\mathrm{T}$ & 1 & T-PLL & Somatic & [83] \\
\hline Q636P & $\mathrm{CD} 2$ & $\mathrm{pY}+3$ & - & $1907 \mathrm{~A}>\mathrm{C}$ & 1 & MEITL & Somatic & [81] \\
\hline \multirow{12}{*}{$\mathrm{N} 642 \mathrm{H}$} & \multirow{12}{*}{$\beta \mathrm{D} 4$} & \multirow{12}{*}{ pY } & \multirow{12}{*}{ Sheinerman } & \multirow{12}{*}{$1924 \mathrm{~A}>\mathrm{C}$} & 39 & MEITL & \multirow{12}{*}{ Somatic } & \multirow{12}{*}[41,62,69,77,80,81,83-102]{} \\
\hline & & & & & 33 & T-PLL & & \\
\hline & & & & & 29 & Eosinophilia & & \\
\hline & & & & & 28 & T-ALL & & \\
\hline & & & & & 7 & HSTL & & \\
\hline & & & & & 11 & LGLL & & \\
\hline & & & & & 3 & PCTL & & \\
\hline & & & & & 3 & Sézary & & \\
\hline & & & & & 1 & AAA & & \\
\hline & & & & & 1 & $\mathrm{CNL}$ & & \\
\hline & & & & & 1 & PTCL, NOS & & \\
\hline & & & & & 1 & AML & & \\
\hline F646S & $\mathrm{DB}^{\prime} 1$ & $\mathrm{pY}+3$ & - & $1937 \mathrm{~T}>\mathrm{C}$ & 1 & GHI & Germline* & [103] \\
\hline T648S & $\mathrm{DB}^{\prime} 3$ & $\mathrm{pY}+3$ & - & $1942 \mathrm{~A}>\mathrm{T}$ & 1 & T-ALL & Somatic & [101] \\
\hline R659C & $\alpha \mathrm{B}^{\prime} 4$ & $\begin{array}{l}\text { Dimer } \\
\text { Inter }\end{array}$ & - & $1975 \mathrm{C}>\mathrm{T}$ & 1 & T-PLL & Somatic & [80] \\
\hline \multirow{5}{*}{ Y665F } & \multirow{5}{*}{$\mathrm{BC}^{*}$} & \multirow{5}{*}{$\begin{array}{l}\text { Dimer } \\
\text { Inter }\end{array}$} & \multirow{5}{*}{ Hydro. Sys. } & \multirow{5}{*}{$1994 \mathrm{~A}>\mathrm{T}$} & 6 & T-PLL & \multirow{5}{*}{ Somatic } & \multirow{5}{*}[43,80,101]{} \\
\hline & & & & & 3 & HSTL & & \\
\hline & & & & & 2 & T-ALL & & \\
\hline & & & & & 2 & NKTL & & \\
\hline & & & & & 5 & LGLL & & \\
\hline $\mathrm{Y} 665 \mathrm{H}$ & $\mathrm{BC}^{*}$ & $\begin{array}{l}\text { Dimer } \\
\text { Inter }\end{array}$ & Hydro. Sys. & $1993 \mathrm{~T}>\mathrm{C}$ & 2 & T-PLL & Somatic & [80] \\
\hline
\end{tabular}

* Patients were homozygous for the point mutation. The final search date for mutations from medical case reports and literature was 30 August, 2019. Abbreviations: AAA, acquired aplastic anemia; AML, acute myeloid leukemia; APL, acute promyelocytic leukemia; CNL, chronic neutrophilic leukemia; GHI, growth hormone insensitivity; HSTL, hepatosplenic T-cell lymphoma; MEITL, monomorphic epitheliotropic intestinal $\mathrm{T}$ cell lymphoma; PCTL, primary cutaneous $\gamma \delta$ T-cell lymphoma; PTCL-NOS, peripheral T-cell lymphoma not-other-specified; T-ALL, T-cell acute lymphoblastic leukemia; T-LGLL, T-cell large granular lymphocytic leukemia; T-PLL, T-cell prolymphocytic leukemia.

Comparatively, homozygous loss of both STAT5 gene products in mice is lethal late in embryonic development, due to the defective erythropoiesis and with loss of STAT5B manifesting with a myriad of physiological effects including sexual dimorphic body growth [104-106]. Clinical cases of patients with STAT5B LOF mutations on both alleles exhibit features similar to growth hormone insensitivity syndrome (GHIS). However, heterozygous human carriers of STAT5B LOF mutations generally do not present with any immunological deficiencies or growth complications, although there have been three germline dominant-negative heterozygous STAT5B mutations recently reported that result in postnatal growth impairment among other physiological symptoms [107]. Although these growth deficiencies are likely multifactorial in etiology, the growth hormone (GH)-growth hormone receptor (GHR) interactions that recruit JAK kinase and stimulate phosphorylation of STAT5B remain intact, suggesting a breakdown in corresponding STAT5B activity. STAT5B LOF patients often carry additional immunological burdens including reduced populations of several T-cell subtypes, suggesting multiple roles for STAT5 in T-cell differentiation [108]. 
Gain-of-function (GOF) germline mutations for STAT3 and STAT5 are rare and clinically diverse. STAT3 GOF mutations present with autoimmune responses, likely due to Th17 clonal expansion which also suppresses regulatory T-cell (Treg) formation. Clinical presentations of STAT3 GOF mutations also show parallels with STAT5 LOF mutations [28]. This is partially an effect of compensatory upregulation of SOCS3 (suppressor of cytokine signaling-3) which strongly inhibits hyperactivated STAT3, but by extension also dampens STAT5 and STAT1 activity. This potently reduces basal levels of STAT5 leading to growth immunodeficiencies.

Contrastingly, multiple de novo somatic GOF mutations arise in STAT3 and STAT5B leading to cancer pathogenesis, and such mutations have been implicated in both solid and liquid tumors. Hyperactivated STAT3 is identified in patients with diverse phenotypes and multiple somatic mutations have been associated with T-LGLL (T-cell large granular lymphocytic leukemia, 40-70\% of all cases) and NK-LGLL (natural killer cell large granular lymphocytic leukemia, 30\% of all cases), as well as different hepatocellular adenomas [40]. STAT5 is upregulated, directly and indirectly, through multiple mechanisms in several hematological malignancies leading to neoplastic transformation. For instance, in $\sim 30 \%$ of acute myeloid leukemia (AML) cases, STAT5B is activated by mutated FLT3 (Fms-Like Tyrosine Kinase 3) [109]. Similarly, $99 \%$ of all chronic myeloid leukemia (CML) cases, which result from the appearance of the Philadelphia chromosome, result in STAT5B hyperactivation [110]. B-cell cancers, such as B-ALL (B-cell acute lymphoid leukemia) and B-CLL (B-cell chronic lymphoid leukemia) are driven by upregulation of IL-7 and IL-22 which also simulate STAT5B [111-113]. Acute and chronic T-cell cancers have lower incidence, but a larger diversity, and are heavily implicated by STAT5B GOF driver mutations $[84,114,115]$. STAT GOF mutations generally stabilize protein structure thereby enhancing transcriptional output, leading to apoptosis-evading and survival phenotypes. LOF mutants generally distort secondary structure and contribute to either loss of activity or increased STAT degradation. Herein, we highlight the structural significance and mechanism of action of malignant STAT3/5B point mutations in the SH2 domain. Notably, STAT5A mutations are less frequently identified which is likely due to the differential roles of the protein isoforms. Although STAT5B has been characterized as a driver in several malignancies, STAT5A has been associated with tumor suppression [116,117]. STAT5A and STAT5B have similar SH2 domains ( 93\% amino acid similarity) with significant changes in the $\beta \mathrm{D}$ strand which likely contributes to varying peptide selectivity.

\subsection{Mutations in the $P Y$ Pocket}

As previously described, the pY pocket is formed by the $\alpha \mathrm{A}$ helix, $\mathrm{BC}$ loop, and one face of the central $\beta$-sheet, and it harbors an overall positive electrostatic potential to stabilize binding with the electronegative phospho-Tyr side-chain (Figure 1). This region of the SH2 domain is characterized by strongly conserved residues that facilitate interactions with the phosphorylated peptide. It includes the $\mathrm{SH} 2$ domain signature sequence as well as a group of 8 phospho-Tyr interacting amino acids that have been collectively referred to as Sheinerman residues [20]. The SH2 domain signature sequence, FLXRXS (where $X$ is a hydrophobic amino acid), corresponds to FLLRFS in all STAT proteins and is located on the $\beta B$ strand. The eight Sheinerman residues correspond to the positions: $\alpha \mathrm{A} 2, \alpha \mathrm{A} 6, \beta \mathrm{B} 5, \beta \mathrm{B} 7, \mathrm{BC} 1, \mathrm{BC} 2, \beta \mathrm{D} 4$ and $\beta \mathrm{D} 6$ [20]. Critically, the $\beta \mathrm{B} 5$ residue is located within the $\mathrm{SH} 2$ domain signature sequence as an invariant Arg residue, which is conserved in 118 of $121 \mathrm{SH} 2$ domain-containing proteins [16]. This indispensable Arg residue is the principal binding partner for phospho-Tyr with the side-chain guanidinium group participating in a bidentate ionic interaction with the phosphate. The side-chains of the $\alpha \mathrm{A} 2$ (Arg/Lys in 118/121 SH2 domains), $\beta B 7$ (Ser in 106/121 $\mathrm{SH} 2$ domains) and $\beta \mathrm{D} 4$ (His in 80/121 SH2 domains) residues also participate in direct interactions with the phospho-Tyr [16]. Notably, the $\alpha$ A2, $\beta B 7$, and $\beta$ D4 residues correspond to Lys591, Glu638, and Ser636 in STAT3 and Lys600, Ser620, and Asn642 in STAT5B. These interactions are highly important for phospho-peptide binding and are reported to contribute to $>50 \%$ of Gibbs free energy of the protein-peptide interaction [16]. The high fidelity of these interactions ostensibly suggests that a mutation at these sites will have a dramatic effect on the activity or binding capacity of STAT3/5. 


\subsubsection{Mutations in Sheinerman Residues}

Mutations identified at the $\alpha$ A2 site in STAT3 (Lys591Glu [30] and Lys591Met [31]) contribute to AD-HIES, a STAT3-deficient malignancy, due to removal of the positively-polarized Lys side-chain that directly coordinates the phospho-Tyr. Similarly, mutations at other critical residues in the pY pocket present with analogous clinical outcomes. Mutation of the invariant $\beta$ B5 position (Arg609Gly [33]) in STAT3 leads to AD-HIES, presenting with reduced expression profiles of Th17 T-cells and high serum levels of IgE (11,300 IU/mL). Replacement of $\beta$ D4 (Ser636Phe [49]) leads to strongly elevated IgE levels $(17,407 \mathrm{IU} / \mathrm{mL})$ with presentation of eczema, abscesses, and pneumonia, also characteristic of AD-HIES pathologies. Interestingly, a patient with a semi-conservative substitution (Ser636Tyr [30]) that retains $\mathrm{H}$-bonding capacity at the $\beta \mathrm{D} 4$ position still presented with a reduced percentage of Th17 cells $(0.31 \%)$ compared to healthy patients $(>1 \%)$, highlighting the substantive role of changes in sterics at the phosphate binding positions. Examining the prevalence of mutations within the remaining Sheinerman residues shows infrequent mutations, such as STAT3 $\beta$ B7 (in which Ser611Gly [34]/Asn [36] have been reported), which also lead to ablation of activity and AD-HIES. In cellulo studies with Ser611Asn indicate a reduced capacity for activation by phosphorylation consistent with altered phospho-Tyr binding [118]. Similarly, substitution at the Sheinerman $\beta$ D6 position is also capable of triggering the AD-HIES phenotype. Notably, this $\beta$ D6 (Glu638Gly $[49,51])$ mutation likely causes gross conformational changes in the $\beta$-sheet due to removal of a complete side-chain. Although mutations in the pY pocket of STAT3 tend to abolish peptide binding, specific mutations in the BC loop lead to either hyperactivation and LGL leukemias or protein dysfunction and AD-HIES. Since the BC loop is directly involved in multiple domain interactions including the $\mathrm{pY}$ and $\mathrm{pY}+3$ pockets, mutations identified in this region will be discussed in detail in Section 3.3.

In STAT5, mutations at the conserved Sheinerman residues have not been identified apart from the $\beta \mathrm{D} 4$ position. In the majority of $\mathrm{SH} 2$ domain-containing proteins, the $\beta \mathrm{D} 4$ residue is a His, directly coordinating the phosphate, and mutagenesis of this residue abolishes peptide binding capacity [16]. As seen with STAT3 (Ser636Tyr), modification in sterics at this position greatly modulates phospho-Tyr peptide binding. In STAT5B, the $\beta D 4$ residue is an Asn642, and the absence of a conserved His residue may represent an evolutionary response to tune down the basal activity of STAT5. Notably, this residue is most frequently mutated in STAT5B (Asn642His) and has been reported in multiple cancer phenotypes (>150 cases [41,62,69,77,80,81,83-102]), most commonly T-cell-prolymphocytic leukemia (T-PLL), monomorphic epitheliotropic intestinal T-cell lymphoma (MEITL), and T-cell acute lymphoblastic leukemia (T-ALL). Asn642His is an extremely aggressive oncodriver of T-cell neoplasia and previous studies have shown multiple T-cell subset organ infiltration and transformation in transgenic mice $[23,119]$. Recently, the crystal structure for the STAT5B Asn642His mutation was reported which suggested different $\mathrm{SH} 2$ domain conformations with either a neatly packed $\beta \mathrm{D}$ strand forming a tight central $\beta$-sheet or a more dissociated $\beta \mathrm{D}$ strand that provides greater access to the SH2 domain [23]. Additionally, different biophysical studies $[23,41]$ have confirmed the substantial increase ( 5-7 fold) in the affinity of pY containing peptides for mutated STAT5B (Asn642His) compared to wild type. This provides a molecular basis for the lower threshold of mutant STAT5B towards cytokine activation and the aggressive phenotype observed in patients. The Asn642His mutation is also predicted to lead to a more stable dimer interface and reduced dephosphorylation kinetics, prolonging the lifetime of the activation state [23].

\subsubsection{Mutations Outside Sheinerman Residues}

The mutational landscape of STAT3 and STAT5B within the pY pocket also extends to less conserved residues, predominantly on the $\beta C$ strand. Mutations at $\beta C 4$ have been identified in both STAT3 (Thr620Ser [33]/Ala [34,49]) and STAT5B (Thr628Ser). In STAT5B, this conservative mutation is commonly observed in T-PLL and T-ALL [86]. In vitro studies with STAT5B Asn642 variants have shown that bulkier substituents in the pY pocket reduce phospho-Tyr affinity [23]. Therefore, the loss of a single methylene group from Thr628 can better accommodate the cognate peptide yielding increased 
transcriptional activity. However, contrary effects are observed with Thr620Ser in STAT3, where this mutation, as well as Thr620Ala, both lead to reduced protein activity and AD-HIES. The contrasting effects of the same mutation at identical positions in STAT3 and STAT5B underscores the unique aspects of each structural motif, and more broadly, the potential for isoform specific drug targeting. Generally, STAT3 is less robust to molecular modifications with slight changes capable of strongly diminishing activity. This is unusual considering the melting temperature of isolated STAT3 $\left(52.5 \pm 0.7^{\circ} \mathrm{C}\right)$ is higher than STAT5B $\left(44.5 \pm 0.3^{\circ} \mathrm{C}\right)$ [120]. The total protein stability is likely the result of both structural and complex protein dynamics and requires further investigation. One destabilizing mutation has been observed in the pY pocket of STAT5B at the $\beta C 4$ position (Ala630Pro [121]) which disrupts the $\beta$-sheet, reducing protein solubility and leading to misfolding and a clinical presentation of severe growth deficiency. Thus, destabilizing mutations are observed in STAT5B, but with a reduced frequency.

\subsection{Mutations in the $p Y+3$ Pocket}

Adjacent to the $\mathrm{pY}$ pocket of the $\mathrm{SH} 2$ domain is the $\mathrm{pY}+3$, or specificity pocket which interacts with C-terminal residues of the phospho-Tyr peptide. The $\beta \mathrm{D}$ strand is critical in facilitating these interactions, particularly the $\beta \mathrm{D} 5$ residue which controls accessibility to this pocket. In Src-type SH2 domains, additional interactions with the cognate phospho-peptide occur between residues in the evolutionary active region (EAR). This includes the $\beta E$ and $\beta F$ strands as well as the loops in between these structural elements. In STAT3 and STAT5, the EAR motif is comprised of an $\alpha$-helix $\left(\alpha B^{\prime}\right)$, and the corresponding interactions occur within the $\mathrm{DB}^{\prime}$ region (loop in between $\beta \mathrm{D}$ strand and $\alpha \mathrm{B}^{\prime}$ helix), $\alpha B^{\prime}$, and $\alpha B$ helices. There is also a clustering of predominantly aromatic, hydrophobic residues at the base of the $\mathrm{pY}+3$ pocket which has been referred to as the hydrophobic system $\left(\beta C 3, \beta C 5, \beta D 3, B C 1^{*}\right.$, and BC3*). In STAT3, this includes residues Phe621 ( $\beta C 3)$, Trp623 ( $\beta C 5)$, Tyr657 $\left(B C 1^{*}\right)$, and Ile659 $\left(\right.$ BC3 $\left.^{*}\right)$ and in STAT5B, Ile629 ( $\left.\beta C 3\right)$, Trp631 ( $\left.\beta C 5\right)$, Phe633 ( $\left.\beta C 7\right)$, Trp641 ( $\left.\beta D 3\right)$, Leu663 (BC1*) and Tyr665 (BC3*). In STAT3, the hydrophobicity of this pocket is reduced by the presence of Gln 635 and Lys626 at the $\beta D 3$ and $\beta C 7$ positions, respectively. The increased polarity leads to a reduced STAT3 preference for phospho-peptides with non-polar residues in the C-terminal positions compared to STAT5B. The $\mathrm{SH} 2$ dimerization interface is in close proximity to the $\mathrm{pY}+3$ pocket and is formed by the $\mathrm{BC}^{*}$ loop, $\alpha \mathrm{B}^{\prime}$ helix and one face of the $\alpha \mathrm{B}$ helix. As such, alterations in the $\mathrm{pY}+3$ pocket directly affect the dimerization interface.

\subsubsection{Mutations in the Hydrophobic System and $\beta D$ Strand}

The pY+3 pocket is a hotspot for STAT SH2 domain mutations. Generally, mutations that increase the polarity of this pocket result in protein destabilization and LOF. This was demonstrated in Epstein-Barr virus (EBV)-transformed B-cells expressing AD-HIES-associated STAT3 mutations. In these assays, the half-life of wild type STAT3 $(25 \pm 2 \mathrm{~h})$ was shown to be substantially reduced by polar mutations at $\beta \mathrm{D} 5$ (Val637Met $=5.3 \pm 4.5 \mathrm{~h}$ ) and BC1* (Tyr657Cys $=5.5 \pm 4.1 \mathrm{~h}$ ) [122]. Conversely, STAT3 mutant Tyr640Phe (DB'1), which is a commonly identified mutation in solid and liquid tumors, leads to constitutive activation across several cell lines (hepatic epithelial cells, lung carcinomas, fibroblasts, etc.) through enhanced stability of STAT3 dimerization, nuclear accumulation and increased transcriptional activity following IFN $\gamma$ stimulation [44,47,48,59-62,65-69]. In wild type STAT3, Tyr640 points directly into the hydrophobic system. Increasing hydrophobicity, through removal of the hydroxyl group tightens the packing of the pocket and enhances the activation potential. The STAT3 Tyr640Phe mutation has been identified in over $>110$ cancer cases in the COSMIC database and is most frequently observed in patients with T-LGLL. An analogous mutation is observed at the $\mathrm{BC}^{*}$ site in STAT5B where the second most frequent mutation (Tyr665Phe) results in STAT5B hyperactivation and has also been observed in patients with T-LGLL.

Within the hydrophobic system, the presence of aromaticity for $\pi-\pi$ stacking interactions from key residue side-chains is strongly favored over non-aromatic Van der Waals interactions. This is especially seen at the $\beta C 3$ position with patients harboring Phe621Val [36,37,50]/Leu [51,52]/Ser [53] 
mutations resulting in STAT3-deficient AD-HIES. In cellulo mutagenesis studies with the Phe621Val mutation have elucidated impaired STAT3 phosphorylation, resulting in defective DNA binding capacity. This strong requirement for aromaticity is also observed in STAT5B, where Tyr665His leads to a hyperactive mutant, since it retains the aromaticity of the imidazole ring to interact with Trp631 $(\beta C 5)$, despite the increase in side-chain polarity.

In addition to the hydrophobic system, the $\beta \mathrm{D}$ strand is critical for controlling pocket accessibility. This is primarily governed by the residue at the $\beta \mathrm{D} 5$ position in $\mathrm{SH} 2$ domains and corresponds to Val637 in STAT3. This residue serves as a selectivity filter, interacting with C-terminal amino acids of the phospho-Tyr peptide. In Src kinase, the $\beta \mathrm{D} 5$ residue corresponds to a Tyr and the aromatic ring is sandwiched between the Glu (pY+1 residue) and Ile (pY+3 residue) of the phospho-peptide [18]. In other $\mathrm{SH} 2$ domain-containing kinases, the $\beta \mathrm{D} 5$ residue interacts with all three $\mathrm{C}$-terminal amino acids of the pY-peptide. Given the critical nature of this site, it is not unexpected that mutations strongly impair STAT3 activity. STAT3 Val637Met has been identified in a number of patient samples ( $>40$ cases) and is associated with AD-HIES due to impaired response to cytokine activation and transcriptional activity. The importance of Val637Met $[30,33,34,36,49,56]$ is further underscored by insensitivity to 100-fold increases in IL-6 to simulate phosphorylation. This inability to recognize specific phospho-peptides contributes to the defective STAT pathway observed in AD-HIES. As a crucial selectivity filter, even semi-conservative mutations Val637Leu [36] and Val637Ala [30] have also been shown to be disruptive to STAT3 activity and result in AD-HIES. Although STAT3 Val637Met may be a result of reduced protein stability [122], circular dichroism spectra for STAT3 Val637Ala suggest that this substitution does not cause large structural perturbations. Alternatively, this substitution likely reduces phospho-peptide binding in the $\mathrm{pY}+3$ pocket [123]. The $\beta \mathrm{D} 7$ position also assists in the orientation of the $\beta D 5$ residue, and mutation of the rigid Pro639 to 639Ala [37]/Ser [30,34]/Thr [35] also results in AD-HIES.

\subsubsection{Mutations in the Dimerization Interface}

In comparison to $\mathrm{pY}$ and $\mathrm{pY}+3$ pockets of the $\mathrm{SH} 2$ domain, the dimerization interface represents a delicate balance in carefully regulating STAT activity. This region is littered with disease-causing mutations and slight changes to sterics or electronics at the $\alpha \mathrm{B}, \alpha \mathrm{B}^{\prime}$, or $\mathrm{BC}^{*}$ loop propagate their effects exponentially and lead to highly contrasting effects. There are multiple examples of such mutations throughout the dimerization interface. For instance, at the $\alpha \mathrm{B}^{\prime} 6$ site, patients with STAT3 Asn647Asp [36,72] exhibit symptoms of AD-HIES, but the Asn647Ile $[57,65,67]$ mutation results in STAT3 hyperactivation manifesting as chronic lymphoproliferative disorder of NK cells (CPLD-NK) and T-LGLL. Comparable to trends observed at the central $\mathrm{pY}+3$ pocket, hydrophobic or aromatic substitutions at the interface stabilize STAT3 dimer formation and subsequent phosphorylation, while changes in polarity, or in this case, an electrostatic reversal, effectively abolish STAT3 activity. Analogous effects are also observed at the $\mathrm{BC} 1^{*}-\mathrm{BC}^{*}$ positions. At $\mathrm{BC} 1^{*}$ and $\mathrm{BC} 2^{*}$, Tyr657Ser [74]/Asn [52]/Cys [30,34,36,58] and Lys658Glu [75] lead to AD-HIES, whereas Tyr657ins [47], Tyr657dup [48,72] and Lys658Met [67,72]/Asn [65]/Tyr [66] elicit several types of T-cell cancers [124]. At the BC3* position, Ile659Leu $[57,72]$ has been characterized in T-LGLL, whereas the recently identified Ile659Asn [58] mutation distorts STAT3 activity leading to AD-HIES. Only destabilizing (AD-HIES causing) mutations have been identified at BC4* (Met660Arg [55] and Met660Thr [76]) in STAT3. The $\mathrm{BC}^{*}$ position was found to be genetically volatile with mutations occurring as Asp661His [65]/Val [78]/Tyr [41,47,48,60,63,65,67,68,72,77]//le [67], with all mutations resulting in STAT3 activation and enhanced response to cytokines. Finally, the BC6* (Ala662) and BC $8 *$ (Asn664) positions are critical SH2 domain interface determinants, where mutagenesis experiments have created artificial disulfide linked STAT3-Ala662Cys-Asn664Cys dimers that are constitutively active in cellulo and induce malignant transformation [66]. This further reinforces the role of the $\mathrm{BC}^{*}$ loop in maintaining the dimer interface to control STAT activity. Individually, these Cys-mutations are likely destabilizing, but their pairing allows for covalent tethering of the STAT3 monomers and active dimer formation. 
Within STAT3, the disordered BC* loop tends to be the only site amenable to insertion/deletion mutations. Since different mutations in this $\mathrm{BC}^{*}$ loop lead to either hyper- or refractory activity, likely the substitutions have some degree of compensatory effect that allow them to persist compared to other regions of the $\mathrm{SH} 2$ domain. Furthermore, the remaining motifs of the $\mathrm{SH} 2$ domain are highly structured and less likely to tolerate insertions or deletions.

The volatility shown by each of the residues in the $\mathrm{BC}^{*}$ loop to trigger such extreme changes in STAT3 behavior underscores both the importance of this region to STAT activity, but also the necessity to understand the underlying molecular dynamics that result in such variability. This is particularly true for the $\mathrm{BC}^{*}$ residue which has no prescribed role in other $\mathrm{SH} 2$ domains. However, as seen above, its malignant capacity is revealed in $>100$ identified cases featuring a mosaic of mutations, according to the COSMIC database. Specifically, the STAT3 Asp661Tyr mutation represents one of the most frequently occurring mutation in the SH2 domain of STAT3 along with Tyr640Phe ( $>100$ cases). Although the increases in hydrophobicity and aromaticity have been speculated as critical determinants for the aggressive nature of this mutation, the site-specific mechanism of activation remains unclear. Notably, both of these frequently cancer-associated mutation sites in STAT3 (Tyr640 and Asp661) are by default Phe and Ile respectively in STAT5B. This substitution to the STAT3 cancer-associated genotype in STAT5B suggests that the protein may be more optimized for protein dimerization. This is an interesting observation and further suggests a delicate evolutionary balance in STAT5B by potentially improving interactions at the dimerization interface while reducing activity through the lack of an efficient phosphate-coordinating $\beta \mathrm{D} 4$ residue (Asn642). The functional significance of these changes in STAT5B, compared to STAT3, has not been biophysically characterized and may also suggest that additional mechanisms are relevant to the disease-associated phenotype including changes to protein stability or transcriptional regulation.

\subsection{Mutations in the Additional Regions of the SH2 Domain}

Mutational hotspots in regions outside the $\mathrm{pY}$ and $\mathrm{pY}+3$ pockets may highlight additional areas that are important for protein regulation and exploitable for drug targeting and understanding disease progression. There is a tight clustering of mutations in the BC loop of STAT3 on the periphery of the pY pocket. Similar to the dimerization interface, mutations at these residues can either enhance or reduce STAT activity. This region is in close proximity to the $\mathrm{pY}$ pocket, $\mathrm{pY}+3$ pocket, dimerization interface, and STAT linker domain and likely serves as an important allosteric communication bridge for interdomain signaling. As such, interactions at this region of the $\mathrm{BC}$ loop require a complex balance of flexibility and rigidity. For instance, at the STAT3 BC3 position, a mutation at Ser614Arg [39-42] leads to hyperactivation and LGLL, whereas a Ser614Gly [34] results in LOF and AD-HIES. Increasing the positive electrostatic potential at this region generally leads to STAT hyperactivation and draws the BC loop closer into the pY pocket. Mutations found at neighboring sites BC5, BC6, and B7 delineate similar trends, where Glu616Lys [45], Glu616Gly [44], Gly617Arg [44], and Gly618Arg [47,48] are found in diffuse large B-cell lymphoma and NK-malignancies. Corresponding electronegative or bulky substitutions are associated with AD-HIES and dysfunctional STAT3 (Gly617Glu [46], Gly618Asp [35,37], and Gly617Val [34]).

There are additional mutations that are located across STAT5 and identified in single patient cases. Given the general robust nature of STAT5 to mutations, it is difficult to assess the oncogenic driving capacity of a single mutation, or whether the disease is multifactorial in etiology. For instance, a mutation in the short $\beta$ A strand was identified within STAT5B as Gly596Val [79]. However, this mutation was identified in a chimeric protein of STAT5B and retinoic acid receptor- $\alpha$ (STAT5B-RAR $\alpha$ ), which is associated with acute promyelocytic leukemia (APL) and is also resistant to all-trans retinoic acid therapy. All-trans retinoic acid (ATRA) is capable of inducing remission in almost all APL cases, with several exceptions [125]. Since this is a rare subtype of APL, where the fusion protein was identified in a small minority of cases $(<10)$, it is difficult to judge the importance of the mutation to the progression of the disease, although the residue is conserved across species. Notably, a STAT3-RAR $\alpha$ 
fusion was also recently discovered in an APL patient with a similar ATRA-resistance profile [126]. Surprisingly, no STAT5A fusions have been discovered. It would be interesting to define if the dimerization mechanism of these RAR $\alpha$ fusions is mediated through a partially intact SH2 domain or other dimerization domain of STAT. Other mutations in STAT5B are located in non-hotspots including Asp634Val ( $\beta C 8)$, Gln636Pro (CD2), and Arg659Cys ( $\alpha$ B4) and were identified in patients with T-PLL and MEITL. Similar to STAT3, these mutations are in close proximity to the dimerization interface and increase the hydrophobicity of the region, which can facilitate hyperactivation. It is interesting to note that T-PLL represents the disease with most hyperactive STAT3/5B and JAK3 mutations among all subgroups of largely untargeted orphan T-cell neoplasias, and future targeting efforts in this pathway will likely benefit these patients.

\section{Conclusions}

Disease associated mutations are more frequently identified in STAT3 compared to STAT5B, suggesting that STAT5B is more robust to the alterations in structural motifs, or that STAT3 has a more pronounced role in normal physiological functioning. However, it is clear that even slight alterations to electronics or sterics in the SH2 domain can dramatically alter STAT3 activity. In STAT3, the majority of mutations identified in the $\mathrm{PY}$ pocket impair protein function, with the most substantial effects observed upon mutation of conserved Sheinerman residues (Figure 1f). In STAT5B, pY mutations are generally activating with the Asn642His substitution occurring most frequently in aggressive T-cell cancers (Figure $1 \mathrm{~g}$ ). The $\mathrm{pY}+3$ specificity pockets are characterized by multiple mutations with variable effects. Broadly, mutations that improve hydrophobicity or introduce aromaticity lead to hyperactivation, while increases in $\mathrm{pY}+3$ pocket polarity or removal of aromatic substituents diminish STAT function. This trend is also observed at the $\mathrm{SH} 2$ domain dimerization interface which is a hot-spot for mutations, and different substitutions at a single position can result in severe loss- or gain-of-function. Finally, the BC loop may be a critical region for allosteric communication pathways throughout the protein and has been evolutionarily tuned for the precise interactions. As such, marginally reducing electronegativity or increasing electropositivity leads to hyper- and hypo-activation, respectively.

Currently, additional structural studies and molecular dynamics simulations are required for a better understanding of the molecular mechanisms of STAT3/5B mutations at different sites within the $\mathrm{SH} 2$ domain. Considering the conformational flexibility of the main binding sites with state-of-the-art computational methods, for example thermodynamic integration, should be more thoroughly exploited in further work. These can be used to propose alternative treatments or highlight therapeutic approaches. For instance, the relative instability of the wild type STAT3 protein is shown to be amplified by AD-HIES-causing mutations. The use of small molecules that can trigger stimulation of protein chaperones to rescue dysfunctional STAT3 mutants has been shown to be effective in cellulo [122]. Alternatively, hyperactivated STAT3 is only marginally more stable than the wild-type protein which may be exploited by degradation enhancing therapeutic strategies such as the use of PROTACs and hydrophobic tagging. These efforts can be extended to STAT5 as well as examining the Asn642His site, as this hot-spot mutation mimics SH2 domain superbinders and is excessively aggressive due to its prime role in the $\mathrm{pY}$ pocket. Collectively, these structural studies offer a predictive approach for understanding the molecular foundations of additional mutations identified in the SH2 domain, based on their location and alterations to pocket electronics and sterics.

Funding: P.T.G is supported by research grants from NSERC (RGPIN-2014-05767), CIHR (MOP-130424, MOP-137036), Canada Research Chair (950-232042), Canadian Cancer Society (703963), Canadian Breast Cancer Foundation (705456) and infrastructure grants from CFI $(33536)$ and the Ontario Research Fund (34876). R.M. is supported by the Austrian Science Fund (FWF) (SFB-F04707, SFB-F06105, under the frame of ERA-NET (I 4157-B)). H.A.N. is supported by the FWF, under the frame of ERA PerMed (I 4218-B). R.M., A.O., and H.A.N. were also generously supported by a private donation from Liechtenstein. D.B. and G.M.K. are supported by OTKA K 116904 (National Research, Development and Innovation Office, Hungary).

Acknowledgments: The authors also thank Open Access Funding by the Austrian Science Fund (FWF).

Conflicts of Interest: The authors declare no competing interests. 


\section{References}

1. Wingelhofer, B.; Neubauer, H.A.; Valent, P.; Han, X.; Constantinescu, S.N.; Gunning, P.T.; Müller, M.; Moriggl, R. Implications of STAT3 and STAT5 signaling on gene regulation and chromatin remodeling in hematopoietic cancer. Leuk. 2018, 32, 1713-1726. [CrossRef]

2. O'Shea, J.J.; Schwartz, D.M.; Villarino, A.V.; Gadina, M.; McInnes, I.B.; Laurence, A. The JAK-STAT pathway: Impact on human disease and therapeutic intervention. Annu. Rev. Med. 2015, 66, 311-328. [CrossRef] [PubMed]

3. Bromberg, J.F.; Wrzeszczynska, M.H.; Devgan, G.; Zhao, Y.; Pestell, R.G.; Albanese, C.; E Darnell, J. Stat3 as an Oncogene. Cell 1999, 98, 295-303. [CrossRef]

4. Tsutsui, M.; Yasuda, H.; Suto, H.; Imai, H.; Isobe, Y.; Sasaki, M.; Kojima, Y.; Oshimi, K.; Sugimoto, K. Frequent STAT3 activation is associated with Mcl-1 expression in nasal NK-cell lymphoma. Int. J. Lab. Hematol. 2010, 32, 419-426. [CrossRef] [PubMed]

5. Passerini, L.; Allan, S.E.; Battaglia, M.; Di Nunzio, S.; Alstad, A.N.; Levings, M.K.; Roncarolo, M.G.; Bacchetta, R. STAT5-signaling cytokines regulate the expression of FOXP3 in CD4+CD25+ regulatory T cells and CD4+ CD25- effector T cells. Int. Immunol. 2008, 20, 421-431. [CrossRef] [PubMed]

6. Mirmohammadsadegh, A.; Hassan, M.; Bardenheuer, W.; Marini, A.; Gustrau, A.; Nambiar, S.; Tannapfel, A.; Bojar, H.; Ruzicka, T.; Hengge, U.R. STAT5 Phosphorylation in Malignant Melanoma Is Important for Survival and Is Mediated Through SRC and JAK1 Kinases. J. Investig. Dermatol. 2006, 126, 2272-2280. [CrossRef] [PubMed]

7. Xu, Q.; Briggs, J.; Park, S.; Niu, G.; Kortylewski, M.; Zhang, S.; Gritsko, T.; Turkson, J.; Kay, H.; Semenza, G.L.; et al. Targeting Stat3 blocks both HIF-1 and VEGF expression induced by multiple oncogenic growth signaling pathways. Oncogene 2005, 24, 5552-5560. [CrossRef]

8. Matsumura, I.; Kitamura, T.; Wakao, H.; Tanaka, H.; Hashimoto, K.; Albanese, C.; Downward, J.; Pestell, R.G.; Kanakura, Y. Transcriptional regulation of the cyclin D1 promoter by STAT5: Its involvement in cytokine-dependent growth of hematopoietic cells. EMBO J. 1999, 18, 1367-1377. [CrossRef]

9. Baik, M.; Yu, J.H.; Hennighausen, L. Growth hormone-STAT5 regulation of growth, hepatocellular carcinoma, and liver metabolism. Ann. New York Acad. Sci. 2011, 1229, 29-37. [CrossRef]

10. Nichane, M.; Ren, X.; Bellefroid, E.J. Self-regulation of Stat3 activity coordinates cell-cycle progression and neural crest specification. EMBO J. 2010, 29, 55-67. [CrossRef]

11. Ali, A.M.; Gómez-Biagi, R.F.; Rosa, D.A.; Lai, P.-S.; Heaton, W.L.; Park, J.S.; Eiring, A.M.; Vellore, N.A.; De Araujo, E.D.; Ball, D.P.; et al. Disarming an Electrophilic Warhead: Retaining Potency in Tyrosine Kinase Inhibitor (TKI)-Resistant CML Lines While Circumventing Pharmacokinetic Liabilities. ChemMedChem 2016, 11, 850-861. [CrossRef] [PubMed]

12. De Araujo, E.D.; Manaswiyoungkul, P.; Erdogan, F.; Qadree, A.K.; Sina, D.; Tin, G.; Toutah, K.; Yuen, K.; Gunning, P.T.; Erodgan, F. A functional in vitro assay for screening inhibitors of STAT5B phosphorylation. J. Pharm. Biomed. Anal. 2019, 162, 60-65. [CrossRef] [PubMed]

13. Wingelhofer, B.; Maurer, B.; Heyes, E.C.; Cumaraswamy, A.A.; Berger-Becvar, A.; De Araujo, E.D.; Orlova, A.; Freund, P.; Ruge, F.; Park, J.; et al. Pharmacologic inhibition of STAT5 in acute myeloid leukemia. Leuk. 2018, 32, 1135-1146. [CrossRef] [PubMed]

14. Elumalai, N.; Berg, A.; Rubner, S.; Blechschmidt, L.; Song, C.; Natarajan, K.; Matysik, J.; Berg, T. Rational development of Stafib-2: A selective, nanomolar inhibitor of the transcription factor STAT5b. Sci. Rep. 2017, 7, 819. [CrossRef]

15. Haftchenary, S.; Luchman, H.A.; Jouk, A.O.; Veloso, A.J.; Page, B.D.G.; Cheng, X.R.; Dawson, S.S.; Grinshtein, N.; Shahani, V.M.; Kerman, K.; et al. Potent Targeting of the STAT3 Protein in Brain Cancer Stem Cells: A Promising Route for Treating Glioblastoma. ACS Med. Chem. Lett. 2013, 4, 1102-1107. [CrossRef]

16. Liu, B.A.; Engelmann, B.W.; Nash, P.D. The language of SH2 domain interactions defines phosphotyrosine-mediated signal transduction. FEBS Lett. 2012, 586, 2597-2605. [CrossRef]

17. Gao, Q.; Hua, J.; Kimura, R.; Headd, J.J.; Fu, X.-Y.; Chin, Y.E. Identification of the Linker-SH2 Domain of STAT as the Origin of the SH2 Domain Using Two-dimensional Structural Alignment. Mol. Cell. Proteom. 2004, 3, 704-714. [CrossRef]

18. Zhou, S. SH2 domains recognize specific phosphopeptide sequences. Cell 1993, 72, 767-778. [CrossRef] 
19. Songyang, Z.; Cantley, L.C. Recognition and specificity in protein tyrosine kinase-mediated signalling. Trends Biochem. Sci. 1995, 20, 470-475. [CrossRef]

20. Gianti, E.; Zauhar, R.J. An SH2 domain model of STAT5 in complex with phospho-peptides define "STAT5 Binding Signatures. " J. Comput. Mol. Des. 2015, 29, 451-470. [CrossRef]

21. Pettersen, E.F.; Goddard, T.D.; Huang, C.C.; Couch, G.S.; Greenblatt, D.M.; Meng, E.C.; Ferrin, T.E. UCSF Chimera?A visualization system for exploratory research and analysis. J. Comput. Chem. 2004, 25, 1605-1612. [CrossRef] [PubMed]

22. Nkansah, E.; Shah, R.; Collie, G.W.; Parkinson, G.N.; Palmer, J.; Rahman, K.M.; Bui, T.T.; Drake, A.F.; Husby, J.; Neidle, S.; et al. Observation of unphosphorylated STAT3 core protein binding to targetdsDNA by PEMSA and X-ray crystallography. FEBS Lett. 2013, 587, 833-839. [CrossRef] [PubMed]

23. De Araujo, E.D.; Erdogan, F.; Neubauer, H.A.; Meneksedag-Erol, D.; Manaswiyoungkul, P.; Eram, M.S.; Seo, H.-S.; Qadree, A.K.; Israelian, J.; Orlova, A.; et al. Structural and functional consequences of the STAT5BN642H driver mutation. Nat. Commun. 2019, 10, 2517. [CrossRef] [PubMed]

24. Mao, X.; Ren, Z.; Parker, G.N.; Sondermann, H.; Pastorello, M.A.; Wang, W.; McMurray, J.S.; Demeler, B.; Darnell, J.E.; Chen, X. Structural Bases of Unphosphorylated STAT1 Association and Receptor Binding. Mol. Cell 2005, 17, 761-771. [CrossRef]

25. Langenfeld, F.; Guarracino, Y.; Arock, M.; Trouve, A.; Tchertanov, L. How Intrinsic Molecular Dynamics Control Intramolecular Communication in Signal Transducers and Activators of Transcription Factor STAT5. PLoS ONE 2015, 10, e0145142. [CrossRef]

26. Takeda, K.; Noguchi, K.; Shi, W.; Tanaka, T.; Matsumoto, M.; Yoshida, N.; Kishimoto, T.; Akira, S. Targeted disruption of the mouse Stat3 gene leads to early embryonic lethality. Proc. Natl. Acad. Sci. USA 1997, 94, 3801-3804. [CrossRef]

27. Purvis, H.A.; Anderson, A.E.; Young, D.A.; Isaacs, J.D.; Hilkens, C.M.U. A Negative Feedback Loop Mediated by STAT3 Limits Human Th17 Responses. J. Immunol. 2014, 193, 1142-1150. [CrossRef]

28. Haddad, E. STAT3: Too much may be worse than not enough! Blood 2015, 125, 583-584. [CrossRef]

29. Laurence, A.D.J.; Uhlig, H.H. When half a glass of STAT3 is just not enough. Blood 2016, 128, 3020-3021. [CrossRef]

30. Woellner, C.; Gertz, E.M.; Schäffer, A.A.; Lagos, M.; Perro, M.; Glocker, E.-O.; Pietrogrande, M.C.; Cossu, F.; Franco, J.L.; Matamoros, N.; et al. Mutations in STAT3 and diagnostic guidelines for hyper-IgE syndrome. J. Allergy Clin. Immunol. 2010, 125, 424-432. [CrossRef]

31. Robinson, W.S.; Arnold, S.R.; Michael, C.F.; Vickery, J.D.; Schoumacher, R.A.; Pivnick, E.K.; Ward, J.C.; Nagabhushanam, V.; Lew, D.B. Case report of a young child with disseminated histoplasmosis and review of hyper immunoglobulin e syndrome (HIES). Clin. Mol. Allergy 2011, 9, 14. [CrossRef] [PubMed]

32. Ma, C.S.; Avery, D.T.; Chan, A.; Batten, M.; Bustamante, J.; Boisson-Dupuis, S.; Arkwright, P.D.; Kreins, A.Y.; Averbuch, D.; Engelhard, D.; et al. Functional STAT3 deficiency compromises the generation of human T follicular helper cells. Blood 2012, 119, 3997-4008. [CrossRef] [PubMed]

33. Zhang, L.-Y.; Tian, W.; Shu, L.; Jiang, L.-P.; Zhan, Y.-Z.; Zhao, X.-D.; Cui, Y.-X.; Tang, X.-M.; Wu, D.-Q.; Yang, X.-Q.; et al. Clinical Features, STAT3 Gene Mutations and Th17 Cell Analysis in Nine Children with Hyper-IgE Syndrome in Mainland China. Scand. J. Immunol. 2013, 78, 258-265. [CrossRef] [PubMed]

34. Chandesris, M.O.; Melki, I.; Natividad, A.; Puel, A.; Fieschi, C.; Yun, L.; Thumerelle, C.; Oksenhendler, E.; Boutboul, D.; Thomas, C.; et al. Autosomal dominant STAT3 deficiency and hyper-IgE syndrome: Molecular, cellular, and clinical features from a French national survey. Medicine (United States) 2012, 91. [CrossRef] [PubMed]

35. Freeman, A.F.; Renner, E.D.; Henderson, C.; Langenbeck, A.; Olivier, K.N.; Hsu, A.P.; Hagl, B.; Boos, A.; Davis, J.; Marciano, B.E.; et al. Lung Parenchyma Surgery in Autosomal Dominant Hyper-IgE Syndrome. J. Clin. Immunol. 2013, 33, 896-902. [CrossRef] [PubMed]

36. Holland, S.M.; DeLeo, F.R.; Elloumi, H.Z.; Hsu, A.P.; Uzel, G.; Brodsky, N.; Freeman, A.F.; Demidowich, A.; Davis, J.; Turner, M.L.; et al. STAT3Mutations in the Hyper-IgE Syndrome. New Engl. J. Med. 2007, 357, 1608-1619. [CrossRef] [PubMed]

37. Heimall, J.; Davis, J.; Shaw, P.A.; Hsu, A.P.; Gu, W.; Welch, P.; Holland, S.M.; Freeman, A.F. Paucity of genotype-phenotype correlations in STAT3 mutation positive Hyper IgE Syndrome (HIES). Clin. Immunol. 2011, 139, 75-84. [CrossRef] 
38. Moreira Varanese, I.; Seminario, A.; Diaz Balve, D.; Uriarte, I.; Belardinelli, G.; Gomez Racio, A.; di Giovanni, D.; Bezrodnik, L. New STAT3 mutation in a patient with Hyper IgE Syndrome (HIGES) without criteria in HIES STAT3 score. Transl. Biomed. 2010, 1. [CrossRef]

39. Qiu, Z.-Y.; Fan, L.; Wang, L.; Qiao, C.; Wu, Y.-J.; Zhou, J.-F.; Xu, W.; Li, J.-Y. STAT3 mutations are frequent in T-cell large granular lymphocytic leukemia with pure red cell aplasia. J. Hematol. Oncol. 2013, 6, 82. [CrossRef]

40. Yan, Y.; Olson, T.L.; Nyland, S.B.; Feith, D.J.; Loughran, T.P. Emergence of a STAT3 mutated NK clone in LGL leukemia. Leuk. Res. Rep. 2015, 4, 4-7. [CrossRef]

41. Kúcúk, C.; Jiang, B.; Hu, X.; Zhang, W.; Chan, J.K.C.; Xiao, W.; Lack, N.; Alkan, C.; Williams, J.C.; Avery, K.N.; et al. Activating mutations of STAT5B and STAT3 in lymphomas derived from $\gamma \delta-\mathrm{T}$ or NK cells. Nat. Commun. 2015, 6, 6025. [CrossRef] [PubMed]

42. Blombery, P.; Thompson, E.R.; Jones, K.; Arnau, G.M.; Lade, S.; Markham, J.F.; Li, J.; Deva, A.; Johnstone, R.W.; Khot, A.; et al. Whole exome sequencing reveals activating JAK1 and STAT3 mutations in breast implant-associated anaplastic large cell lymphoma anaplastic large cell lymphoma. Haematol. 2016, 101, e387-e390. [CrossRef] [PubMed]

43. McKinney, M.; Moffitt, A.B.; Gaulard, P.; Travert, M.; De Leval, L.; Nicolae, A.; Raffeld, M.; Jaffe, E.S.; Pittaluga, S.; Xi, L.; et al. The Genetic Basis of Hepatosplenic T-cell Lymphoma. Cancer Discov. 2017, 7, 369-379. [CrossRef] [PubMed]

44. Ohgami, R.S.; Ma, L.; Monabati, A.; Zehnder, J.L.; Arber, D.A. STAT3 mutations are present in aggressive B-cell lymphomas including a subset of diffuse large B-cell lymphomas with CD30 expression. Haematol. 2014, 99, e105-e107. [CrossRef] [PubMed]

45. Song, T.L.; Nairismägi, M.L.; Laurensia, Y.; Lim, J.Q.; Tan, J.; Li, Z.M.; Kizhakeyil, A.; Wijaya, G.C.; Huang, D.C.; Nagarajan, S.; et al. Oncogenic activation of the STAT3 pathway drives PD-L1 expression in natural killer/T-cell lymphoma. Blood 2018, 132, 1146-1158. [CrossRef] [PubMed]

46. Schimke, L.F.; Sawalle-Belohradsky, J.; Roesler, J.; Wollenberg, A.; Rack, A.; Borte, M.; Rieber, N.; Cremer, R.; Maaß, E.; Dopfer, R.; et al. Diagnostic approach to the hyper-IgE syndromes: Immunologic and clinical key findings to differentiate hyper-IgE syndromes from atopic dermatitis. J. Allergy Clin. Immunol. 2010, 126, 611-617. [CrossRef] [PubMed]

47. Couronné, L.; Scourzic, L.; Pilati, C.; Della Valle, V.; Duffourd, Y.; Solary, E.; Vainchenker, W.; Merlio, J.-P.; Beylot-Barry, M.; Damm, F.; et al. STAT3 mutations identified in human hematologic neoplasms induce myeloid malignancies in a mouse bone marrow transplantation model. Haematol. 2013, 98, 1748-1752. [CrossRef]

48. Kristensen, T.; Larsen, M.; Rewes, A.; Frederiksen, H.; Thomassen, M.; Møller, M.B. Clinical Relevance of Sensitive and Quantitative STAT3 Mutation Analysis Using Next-Generation Sequencing in T-Cell Large Granular Lymphocytic Leukemia. J. Mol. Diagn. 2014, 16, 382-392. [CrossRef]

49. Renner, E.D.; Rylaarsdam, S.; Añover-Sombke, S.; Rack, A.L.; Reichenbach, J.; Carey, J.C.; Zhu, Q.; Jansson, A.F.; Barboza, J.; Schimke, L.F.; et al. Novel signal transducer and activator of transcription 3 (STAT3) mutations, reduced $\mathrm{T}(\mathrm{H}) 17$ cell numbers, and variably defective STAT3 phosphorylation in hyper-IgE syndrome. J. Allergy Clin. Immunol. 2008, 122, 181-187. [CrossRef]

50. Odio, C.D.; Milligan, K.L.; Mc Gowan, K.; Spergel, A.K.R.; Bishop, R.; Boris, L.; Urban, A.; Welch, P.; Heller, T.; Kleiner, D.; et al. Endemic mycoses in patients with STAT3-mutated hyper-IgE (Job) syndrome. J. Allergy Clin. Immunol. 2015, 136, 1411-1413. [CrossRef]

51. Kumánovics, A.; Wittwer, C.T.; Pryor, R.J.; Augustine, N.H.; Leppert, M.F.; Carey, J.C.; Ochs, H.D.; Wedgwood, R.J.; Faville, R.J.; Quie, P.G.; et al. Rapid Molecular Analysis of the STAT3 Gene in Job Syndrome of Hyper-IgE and Recurrent Infectious Diseases. J. Mol. Diagn. 2010, 12, 213-219. [CrossRef] [PubMed]

52. Ives, M.L.; Ma, C.S.; Palendira, U.; Chan, A.; Bustamante, J.; Boisson-Dupuis, S.; Arkwright, P.D.; Engelhard, D.; Averbuch, D.; Magdorf, K.; et al. Signal transducer and activator of transcription 3 (STAT3) mutations underlying autosomal dominant hyper-IgE syndrome impair human CD8 + T-cell memory formation and function. J. Allergy Clin. Immunol. 2013, 132, 400-411. [CrossRef] [PubMed]

53. Mogensen, T.H.; Jakobsen, M.A.; Larsen, C.S. Identification of a novel STAT3 mutation in a patient with hyper-IgE syndrome. Scand. J. Infect. Dis. 2013, 45, 235-238. [CrossRef] [PubMed]

54. Bellon, M.; Lu, L.; Nicot, C. Constitutive activation of Pim1 kinase is a therapeutic target for adult T-cell leukemia. Blood 2016, 127, 2439-2450. [CrossRef] 
55. Giacomelli, M.; Tamassia, N.; Moratto, D.; Bertolini, P.; Bertulli, C.; Plebani, A.; Cassatella, M.; Ricci, G.; Bazzoni, F.; Badolato, R. SH2-domain mutations in STAT3 in hyper-IgE syndrome patients result in impairment of IL-10 function. Eur. J. Immunol. 2011, 41, 3075-3084. [CrossRef]

56. Jiao, H.; Tóth, B.; Erdős, M.; Fransson, I.; Rakoczi, E.; Balogh, I.; Magyarics, Z.; Dérfalvi, B.; Csorba, G.; Szaflarska, A.; et al. Novel and recurrent STAT3 mutations in hyper-IgE syndrome patients from different ethnic groups. Mol. Immunol. 2008, 46, 202-206. [CrossRef]

57. Shi, M.; He, R.; Feldman, A.L.; Viswanatha, D.S.; Jevremovic, D.; Chen, D.; Morice, W.G. STAT3 mutation and its clinical and histopathologic correlation in T-cell large granular lymphocytic leukemia. Hum. Pathol. 2018, 73, 74-81. [CrossRef]

58. Goncalves, M.R.; Junior, P.R. Association between STAT3 mutations and phenotypic features in Hyper-IgE Syndrome. J. Allergy Clin. Immunol. 2019, 143, AB111. [CrossRef]

59. Calderaro, J.; Nault, J.C.; Balabaud, C.; Couchy, G.; Saint-Paul, M.C.; Azoulay, D.; Mehdaoui, D.; Luciani, A.; Zafrani, E.S.; Bioulac-Sage, P.; et al. Inflammatory hepatocellular adenomas developed in the setting of chronic liver disease and cirrhosis. Mod. Pathol. 2016, 29, 43-50. [CrossRef]

60. Dufva, O.; Kankainen, M.; Kelkka, T.; Sekiguchi, N.; Awad, S.A.; Eldfors, S.; Yadav, B.; Kuusanmäki, H.; Malani, D.; Andersson, E.I.; et al. Aggressive natural killer-cell leukemia mutational landscape and drug profiling highlight JAK-STAT signaling as therapeutic target. Nat. Commun. 2018, 9, 1567. [CrossRef]

61. Kataoka, K.; Nagata, Y.; Kitanaka, A.; Shiraishi, Y.; Shimamura, T.; Yasunaga, J.-I.; Totoki, Y.; Chiba, K.; Sato-Otsubo, A.; Nagae, G.; et al. Integrated molecular analysis of adult T cell leukemia/lymphoma. Nat. Genet. 2015, 47, 1304-1315. [CrossRef] [PubMed]

62. Kiel, M.J.; Sahasrabuddhe, A.A.; Rolland, D.C.M.; Velusamy, T.; Chung, F.; Schaller, M.; Bailey, N.G.; Betz, B.L.; Miranda, R.N.; Porcu, P.; et al. Genomic analyses reveal recurrent mutations in epigenetic modifiers and the JAK-STAT pathway in Sézary syndrome. Nat. Commun. 2015, 6, 8470. [CrossRef] [PubMed]

63. Ishida, F.; Matsuda, K.; Sekiguchi, N.; Makishima, H.; Taira, C.; Momose, K.; Nishina, S.; Senoo, N.; Sakai, H.; Ito, T.; et al. STAT3 gene mutations and their association with pure red cell aplasia in large granular lymphocyte leukemia. Cancer Sci. 2014, 105, 342-346. [CrossRef] [PubMed]

64. Bergmann, A.K.; Fataccioli, V.; Castellano, G.; Martin-Garcia, N.; Pelletier, L.; Ammerpohl, O.; Bergmann, J.; Bhat, J.; Pau, E.C.; Martín-Subero, J.I.; et al. DNA methylation profiling of hepatosplenic t-cell lymphoma. Haematologica 2019, 104, e104-e107. [CrossRef] [PubMed]

65. Koskela, H.L.M.; Eldfors, S.; Ellonen, P.; van Adrichem, A.J.; Kuusanmäki, H.; Andersson, E.I.; Lagström, S.; Clemente, M.J.; Olson, T.; Jalkanen, S.E.; et al. Somatic STAT3 mutations in large granular lymphocytic leukemia. N. Engl. J. Med. 2012, 366, 1905-1913. [CrossRef] [PubMed]

66. Pilati, C.; Amessou, M.; Bihl, M.P.; Balabaud, C.; Van Nhieu, J.T.; Paradis, V.; Nault, J.C.; Izard, T.; Bioulac-Sage, P.; Couchy, G.; et al. Somatic mutations activating STAT3 in human inflammatory hepatocellular adenomas. J. Exp. Med. 2011, 208, 1359-1366. [CrossRef]

67. Jerez, A.; Clemente, M.J.; Makishima, H.; Koskela, H.; Leblanc, F.; Ng, K.P.; Olson, T.; Przychodzen, B.; Afable, M.; Gomez-Segui, I.; et al. STAT3 mutations unify the pathogenesis of chronic lymphoproliferative disorders of NK cells and T-cell large granular lymphocyte leukemia. Blood 2012, 120, 3048-3057. [CrossRef]

68. Ohgami, R.S.; Ma, L.; Merker, J.D.; Martinez, B.; Zehnder, J.L.; Arber, D.A. STAT3 mutations are frequent in CD30+ T-cell lymphomas and T-cell large granular lymphocytic leukemia. Leukemia 2013, 27, $2244-2247$. [CrossRef]

69. Nicolae, A.; Xi, L.; Pittaluga, S.; Abdullaev, Z.; Pack, S.D.; Chen, J.; Waldmann, T.A.; Jaffe, E.S.; Raffeld, M. Frequent STAT5B mutations in $\gamma \delta$ hepatosplenic T-cell lymphomas. Leuk. 2014, 28, 2244-2248. [CrossRef]

70. Ma, C.S.; Chew, G.Y.; Simpson, N.; Priyadarshi, A.; Wong, M.; Grimbacher, B.; Fulcher, D.A.; Tangye, S.G.; Cook, M.C. Deficiency of Th17 cells in hyper IgE syndrome due to mutations in STAT3. J. Exp. Med. 2008, 205, 1551-1557. [CrossRef]

71. Flanagan, S.E.; Haapaniemi, E.; Russell, M.A.; Caswell, R.; Allen, H.L.; De Franco, E.; McDonald, T.J.; Rajala, H.; Ramelius, A.; Barton, J.; et al. Activating germline mutations in STAT3 cause early-onset multi-organ autoimmune disease. Nat. Genet. 2014, 46, 812-814. [CrossRef] [PubMed]

72. Fasan, A.; Kern, W.; Grossmann, V.; Haferlach, C.; Haferlach, T.; Schnittger, S. STAT3 mutations are highly specific for large granular lymphocytic leukemia. Leukemia 2013, 27, 1598-1600. [CrossRef] [PubMed]

73. Kim, M.S.; Lee, S.H.; Yoo, N.J.; Lee, S.H. STAT3 exon 21 mutation is rare in common human cancers. Acta Oncol. 2013, 52, 1221-1222. [CrossRef] [PubMed] 
74. Liu, J.Y.; Li, Q.; Chen, T.T.; Guo, X.; Ge, J.; Yuan, L.X. Destructive pulmonary staphylococcal infection in a boy with hyper-IgE syndrome: A novel mutation in the signal transducer and activator of transcription 3 (STAT3) gene (p.Y657S). Eur. J. Pediatr. 2011, 170, 661-666. [CrossRef]

75. Milner, J.D.; Vogel, T.P.; Forbes, L.; Ma, C.A.; Stray-Pedersen, A.; Niemela, J.E.; Lyons, J.J.; Engelhardt, K.R.; Zhang, Y.; Topcagic, N.; et al. Early-onset lymphoproliferation and autoimmunity caused by germline STAT3 gain-of-function mutations. Blood 2015, 125, 591-599. [CrossRef]

76. Saikia, B.; Goel, S.; Suri, D.; Minz, R.W.; Rawat, A.; Singh, S. Novel Mutation in SH2 Domain of STAT3 (p.M660T) in Hyper-IgE Syndrome with Sterno-Clavicular and Paravertebral Abscesses. Indian J. Pediatr. 2017, 203, 244-495. [CrossRef]

77. Teramo, A.; Barila, G.; Calabretto, G.; Ercolin, C.; Lamy, T.; Moignet, A.; Roussel, M.; Pastoret, C.; Leoncin, M.; Gattazzo, C.; et al. STAT3 mutation impacts biological and clinical features of T-LGL leukemia. Oncotarget 2017, 8, 61876-61889. [CrossRef]

78. Crescenzo, R.; Abate, F.; Lasorsa, E.; Tabbo', F.; Gaudiano, M.; Chiesa, N.; Di Giacomo, F.; Spaccarotella, E.; Barbarossa, L.; Ercole, E.; et al. Convergent mutations and kinase fusions lead to oncogenic STAT3 activation in anaplastic large cell lymphoma. Cancer Cell 2015, 27, 516-532. [CrossRef]

79. Iwanaga, E.; Nakamura, M.; Nanri, T.; Kawakita, T.; Horikawa, K.; Mitsuya, H.; Asou, N. Acute promyelocytic leukemia harboring a STAT5B-RARA fusion gene and a G596V missense mutation in the STAT5B SH2 domain of the STAT5B-RARA. Eur. J. Haematol. 2009, 83, 499-501. [CrossRef]

80. Kiel, M.J.; Velusamy, T.; Rolland, D.; Sahasrabuddhe, A.A.; Chung, F.; Bailey, N.G.; Schrader, A.; Li, B.; Li, J.Z.; Ozel, A.B.; et al. Integrated genomic sequencing reveals mutational landscape of T-cell prolymphocytic leukemia. Blood 2014, 124, 1460-1472. [CrossRef]

81. Roberti, A.; Dobay, M.P.; Bisig, B.; Vallois, D.; Boéchat, C.; Lanitis, E.; Bouchindhomme, B.; Parrens, M.-C.; Bossard, C.; Quintanilla-Martinez, L.; et al. Type II enteropathy-associated T-cell lymphoma features a unique genomic profile with highly recurrent SETD2 alterations. Nat. Commun. 2016, 7, 12602-12613. [CrossRef] [PubMed]

82. Chia, D.J.; Subbian, E.; Buck, T.M.; Hwa, V.; Rosenfeld, R.G.; Skach, W.R.; Shinde, U.; Rotwein, P. Aberrant folding of a mutant $\mathrm{Stat} 5 \mathrm{~b}$ causes growth hormone insensitivity and proteasomal dysfunction. J. Biol. Chem. 2006, 281, 6552-6558. [CrossRef] [PubMed]

83. Schrader, A.; Crispatzu, G.; Oberbeck, S.; Mayer, P.; Pützer, S.; Von Jan, J.; Vasyutina, E.; Warner, K.; Weit, N.; Pflug, N.; et al. Actionable perturbations of damage responses by TCL1/ATM and epigenetic lesions form the basis of T-PLL. Nat. Commun. 2018, 9, 697. [CrossRef] [PubMed]

84. Rajala, H.L.M.; Eldfors, S.; Kuusanmäki, H.; Van Adrichem, A.J.; Olson, T.; Lagström, S.; Andersson, E.I.; Jerez, A.; Clemente, M.J.; Yan, Y.; et al. Discovery of somatic STAT5b mutations in large granular lymphocytic leukemia. Blood 2013, 121, 4541-4550. [CrossRef] [PubMed]

85. Babushok, D.V.; Perdigones, N.; Perin, J.C.; Olson, T.S.; Ye, W.; Roth, J.J.; Lind, C.; Cattier, C.; Li, Y.; Hartung, H.; et al. Emergence of clonal hematopoiesis in the majority of patients with acquired aplastic anemia. Cancer Genet. 2015, 208, 115-128. [CrossRef]

86. Lopez, C.; Bergmann, A.K.; Paul, U.; Penas, E.M.M.; Nagel, I.; Betts, M.; Johansson, P.; Ritgen, M.; Baumann, T.; Aymerich, M.; et al. Genes encoding members of the JAK-STAT pathway or epigenetic regulators are recurrently mutated in T-cell prolymphocytic leukaemia. Br. J. Haematol. 2016, 173, $265-273$. [CrossRef]

87. Andersson, E.I.; Tanahashi, T.; Sekiguchi, N.; Gasparini, V.R.; Bortoluzzi, S.; Kawakami, T.; Matsuda, K.; Mitsui, T.; Eldfors, S.; Bortoluzzi, S.; et al. High incidence of activating STAT5B mutations in CD4-positive T-cell large granular lymphocyte leukemia. Blood 2016, 128, 2465-2468. [CrossRef]

88. Andersson, E.I.; Pützer, S.; Yadav, B.; Dufva, O.; Khan, S.; He, L.; Sellner, L.; Schrader, A.; Crispatzu, G.; Oleś, M.; et al. Discovery of novel drug sensitivities in T-PLL by high-throughput ex vivo drug testing and mutation profiling. Leukemia 2018, 32, 774-787. [CrossRef]

89. Bandapalli, O.R.; Schuessele, S.; Kunz, J.B.; Rausch, T.; Stütz, A.M.; Tal, N.; Geron, I.; Gershman, N.; Izraeli, S.; Eilers, J.; et al. The activating STAT5B N642H mutation is a common abnormality in pediatric T-cell acute lymphoblastic leukemia and confers a higher risk of relapse. Haematol. 2014, 99, e188-e192. [CrossRef] 
90. Atak, Z.K.; Gianfelici, V.; Hulselmans, G.; De Keersmaecker, K.; Devasia, A.G.; Geerdens, E.; Mentens, N.; Chiaretti, S.; Durinck, K.; Uyttebroeck, A.; et al. Comprehensive Analysis of Transcriptome Variation Uncovers Known and Novel Driver Events in T-Cell Acute Lymphoblastic Leukemia. PLoS Genet. 2013, 9, e1003997.

91. Nairismägi, M.-L.; Tan, J.; Lim, J.Q.; Nagarajan, S.; Ng, C.C.Y.; Rajasegaran, V.; Huang, D.; Lim, W.K.; Laurensia, Y.; Wijaya, G.C.; et al. JAK-STAT and G-protein-coupled receptor signaling pathways are frequently altered in epitheliotropic intestinal T-cell lymphoma. Leuk. 2016, 30, 1311-1319. [CrossRef] [PubMed]

92. Lavallée, V.-P.; Krošl, J.; Lemieux, S.; Boucher, G.; Gendron, P.; Pabst, C.; Boivin, I.; Marinier, A.; Guidos, C.J.; Meloche, S.; et al. Chemo-genomic interrogation of CEBPA mutated AML reveals recurrent CSF3R mutations and subgroup sensitivity to JAK inhibitors. Blood 2016, 127, 3054-3061. [CrossRef] [PubMed]

93. Luo, Q.; Shen, J.; Yang, Y.; Tang, H.; Shi, M.; Liu, J.; Liu, Z.; Shi, X.; Yi, Y. CSF3R T618I, ASXL1 G942 fs and STAT5B N642H trimutation co-contribute to a rare chronic neutrophilic leukaemia manifested by rapidly progressive leucocytosis, severe infections, persistent fever and deep venous thrombosis. Br. J. Haematol. 2018, 180, 892-894. [CrossRef] [PubMed]

94. Prasad, A.; Rabionet, R.; Espinet, B.; Zapata, L.; Puiggros, A.; Melero, C.; Puig, A.; Sarria-Trujillo, Y.; Ossowski, S.; García-Muret, M.P.; et al. Identification of Gene Mutations and Fusion Genes in Patients with Sézary Syndrome. J. Investig. Dermatol. 2016, 136, 1490-1499. [CrossRef]

95. Ma, X.; Wen, L.; Wu, L.; Wang, Q.; Yao, H.; Wang, Q.; Ma, L.; Chen, S. Rare occurrence of a STAT5B N642H mutation in adult T-cell acute lymphoblastic leukemia. Cancer Genet. 2015, 208, 52-53. [CrossRef]

96. Cross, N.C.P.; Hoade, Y.; Tapper, W.J.; Carreno-Tarragona, G.; Fanelli, T.; Jawhar, M.; Naumann, N.; Pieniak, I.; Lübke, J.; Ali, S.; et al. Recurrent activating STAT5B N642H mutation in myeloid neoplasms with eosinophilia. Leukemia 2019, 33, 415-425. [CrossRef]

97. Ma, C.A.; Xi, L.; Cauff, B.; DeZure, A.; Freeman, A.F.; Hambleton, S.; Kleiner, G.; Leahy, T.R.; O'Sullivan, M.; Makiya, M.; et al. Somatic STAT5b gain-of-function mutations in early onset nonclonal eosinophilia, urticaria, dermatitis, and diarrhea. Blood 2017, 129, 650-653. [CrossRef]

98. Baer, C.; Muehlbacher, V.; Kern, W.; Haferlach, C.; Haferlach, T. Molecular genetic characterization of myeloid/lymphoid neoplasms associated with eosinophilia and rearrangement of PDGFRA, PDGFRB, FGFR1 or PCM1-JAK2. Haematol. 2018, 103, e348-e350. [CrossRef]

99. Simpson, H.M.; Khan, R.Z.; Song, C.; Sharma, D.; Sadashivaiah, K.; Furusawa, A.; Liu, X.; Nagaraj, S.; Sengamalay, N.; Sadzewicz, L.; et al. Concurrent Mutations in ATM and Genes Associated with Common $\gamma$ Chain Signaling in Peripheral T Cell Lymphoma. PLoS ONE 2015, 10, e0141906. [CrossRef]

100. Jiang, L.; Gu, Z.-H.; Yan, Z.-X.; Zhao, X.; Xie, Y.-Y.; Zhang, Z.-G.; Pan, C.-M.; Hu, Y.; Cai, C.-P.; Dong, Y.; et al. Exome sequencing identifies somatic mutations of DDX3X in natural killer/T-cell lymphoma. Nat. Genet. 2015, 47, 1061-1066. [CrossRef]

101. Kontro, M.; Kuusanmäki, H.; Eldfors, S.; Burmeister, T.; Andersson, E.I.; Bruserud, O.; Brümmendorf, T.H.; Edgren, H.; Gjertsen, B.T.; Itälä-Remes, M.; et al. Novel activating STAT5B mutations as putative drivers of T-cell acute lymphoblastic leukemia. Leukemia 2014, 28, 1738-1742. [CrossRef] [PubMed]

102. Menon, M.P.; Nicolae, A.; Meeker, H.; Raffeld, M.; Xi, L.; Jegalian, A.G.; Miller, D.C.; Pittaluga, S.; Jaffe, E.S. Primary CNS T-cell Lymphomas: A Clinical, Morphologic, Immunophenotypic, and Molecular Analysis. Am. J. Surg. Pathol. 2015, 39, 1719-1729. [CrossRef] [PubMed]

103. Varco-Merth, B.; Feigerlová, E.; Shinde, U.; Rosenfeld, R.G.; Hwa, V.; Rotwein, P. Severe growth deficiency is associated with STAT5b mutations that disrupt protein folding and activity. Mol. Endocrinol. 2013, 27, 150-161. [CrossRef] [PubMed]

104. Hwa, V. STAT5B deficiency: Impacts on human growth and immunity. Growth Horm. IGF Res. 2016, 28, 16-20. [CrossRef]

105. Cui, Y.; Riedlinger, G.; Miyoshi, K.; Tang, W.; Li, C.; Deng, C.-X.; Robinson, G.W.; Hennighausen, L. Inactivation of Stat5 in Mouse Mammary Epithelium during Pregnancy Reveals Distinct Functions in Cell Proliferation, Survival, and Differentiation. Mol. Cell. Boil. 2004, 24, 8037-8047. [CrossRef]

106. Hoelbl, A.; Kovacic, B.; Kerenyi, M.A.; Simma, O.; Warsch, W.; Cui, Y.; Beug, H.; Hennighausen, L.; Moriggl, R.; Sexl, V. Clarifying the role of Stat 5 in lymphoid development and Abelson-induced transformation. Blood 2006, 107, 4898-4906. [CrossRef] 
107. Klammt, J.; Neumann, D.; Gevers, E.F.; Andrew, S.F.; Schwartz, I.D.; Rockstroh, D.; Colombo, R.; Sanchez, M.A.; Vokurkova, D.; Kowalczyk, J.; et al. Dominant-negative STAT5B mutations cause growth hormone insensitivity with short stature and mild immune dysregulation. Nat. Commun. 2018, 9, 2105. [CrossRef]

108. Kanai, T.; Jenks, J.; Nadeau, K.C. The STAT5b Pathway Defect and Autoimmunity. Front. Immunol. $2012,3,3$. [CrossRef]

109. Sallmyr, A.; Fan, J.; Datta, K.; Kim, K.-T.; Grosu, D.; Shapiro, P.; Small, D.; Rassool, F. Internal tandem duplication of FLT3 (FLT3/ITD) induces increased ROS production, DNA damage, and misrepair: Implications for poor prognosis in AML. Blood 2008, 111, 3173-3182. [CrossRef]

110. Warsch, W.; Kollmann, K.; Eckelhart, E.; Fajmann, S.; Cerny-Reiterer, S.; Hölbl, A.; Gleixner, K.V.; Dworzak, M.; Mayerhofer, M.; Hoermann, G.; et al. High STAT5 levels mediate imatinib resistance and indicate disease progression in chronic myeloid leukemia. Blood 2011, 117, 3409-3420. [CrossRef]

111. Ribeiro, D.; Melão, A.; Van Boxtel, R.; Santos, C.I.; Silva, A.; Silva, M.C.; Cardoso, B.A.; Coffer, P.J.; Barata, J.T. STAT5 is essential for IL-7-mediated viability, growth, and proliferation of T-cell acute lymphoblastic leukemia cells. Blood Adv. 2018, 2, 2199-2213. [CrossRef] [PubMed]

112. Wang, Z.; Bunting, K.D. STAT5 activation in B-cell acute lymphoblastic leukemia: Damned if you do, damned if you don't. Cancer Cell Microenviron. 2016, 3, 1186.

113. Chiorazzi, N. Cell proliferation and death: Forgotten features of chronic lymphocytic leukemia B cells. Best Pr. Res. Clin. Haematol. 2007, 20, 399-413. [CrossRef] [PubMed]

114. Rajala, H.L.M.; Mustjoki, S. STAT5b in LGL leukemia-A novel therapeutic target? Oncotarget 2013, 4, 808-809. [CrossRef]

115. Mitchell, T.J.; Whittaker, S.J.; John, S. Dysregulated expression of COOH-terminally truncated Stat5 and loss of IL2-inducible Stat5-dependent gene expression in Sezary Syndrome. Cancer Res. 2003, 63, 9048-9054.

116. Zhang, Q.; Wang, H.Y.; Liu, X.; A Wasik, M. STAT5A is epigenetically silenced by the tyrosine kinase NPM1-ALK and acts as a tumor suppressor by reciprocally inhibiting NPM1-ALK expression. Nat. Med. 2007, 13, 1341-1348. [CrossRef]

117. Kollmann, S.; Grundschober, E.; Maurer, B.; Warsch, W.; Grausenburger, R.; Edlinger, L.; Huuhtanen, J.; Lagger, S.; Hennighausen, L.; Valent, P.; et al. Twins with different personalities: STAT5B-but not STAT5A-has a key role in BCR/ABL-induced leukemia. Leuk. 2019, 33, 1583-1597. [CrossRef]

118. He, J.; Shi, J.; Xu, X.; Zhang, W.; Wang, Y.; Chen, X.; Du, Y.; Zhu, N.; Zhang, J.; Wang, Q.; et al. STAT3 mutations correlated with hyper-IgE syndrome lead to blockage of IL-6/STAT3 signalling pathway. J. Biosci. 2012, 37, 243-257. [CrossRef]

119. Pham, H.T.T.; Maurer, B.; Prchal-Murphy, M.; Grausenburger, R.; Grundschober, E.; Javaheri, T.; Nivarthi, H.; Boersma, A.; Kolbe, T.; Elabd, M.; et al. STAT5B N642H is a driver mutation for T cell neoplasia. J. Clin. Investig. 2018, 128, 387-401. [CrossRef]

120. De Araujo, E.D.; Manaswiyoungkul, P.; Israelian, J.; Park, J.; Yuen, K.; Farhangi, S.; Berger-Becvar, A.; Abu-Jazar, L.; Gunning, P.T. High-throughput thermofluor-based assays for inhibitor screening of STAT SH2 domains. J. Pharm. Biomed. Anal. 2017, 143, 159-167. [CrossRef]

121. Kofoed, E.M.; Hwa, V.; Woods, K.A.; Buckway, C.K.; Tsubaki, J.; Pratt, K.L.; Bezrodnik, L.; Tepper, A.; Little, B.; Jasper, H.; et al. Growth Hormone Insensitivity Associated with aSTAT5bMutation. New Engl. J. Med. 2003, 349, 1139-1147. [CrossRef] [PubMed]

122. Bocchini, C.E.; Nahmod, K.; Katsonis, P.; Kim, S.; Kasembeli, M.M.; Freeman, A.; Lichtarge, O.; Makedonas, G.; Tweardy, D.J. Protein stabilization improves STAT3 function in autosomal dominant hyper-IgE syndrome. Blood 2016, 128, 3061-3072. [CrossRef] [PubMed]

123. Brambilla, L.; Genini, D.; Laurini, E.; Merulla, J.; Perez, L.; Fermeglia, M.; Carbone, G.M.; Pricl, S.; Catapano, C.V. Hitting the right spot: Mechanism of action of OPB-31121, a novel and potent inhibitor of the Signal Transducer and Activator of Transcription 3 (STAT3). Mol. Oncol. 2015, 9, 1194-1206. [CrossRef] [PubMed]

124. Chandrasekaran, P.; Zimmerman, O.; Paulson, M.; Sampaio, E.P.; Freeman, A.F.; Sowerwine, K.J.; Hurt, D.; Alcántara-Montiel, J.C.; Hsu, A.P.; Holland, S.M. Distinct mutations at the same positions of STAT3 cause either loss or gain of function. J. Allergy Clin. Immunol. 2016, 138, 1222-1224. [CrossRef] [PubMed] 
125. Avvisati, G.; Tallman, M.S. All-trans retinoic acid in acute promyelocytic leukaemia. Best Pr. Res. Clin. Haematol. 2003, 16, 419-432. [CrossRef]

126. Yao, L.; Wen, L.; Wang, N.; Liu, T.; Xu, Y.; Ruan, C.; Wu, D.; Chen, S. Identification of novel recurrent STAT3-RARA fusions in acute promyelocytic leukemia lacking t(15;17)(q22;q12)/PML-RARA. Blood 2018, 131, 935-939. [CrossRef] [PubMed] article distributed under the terms and conditions of the Creative Commons Attribution (CC BY) license (http://creativecommons.org/licenses/by/4.0/). 